\title{
47. THE PALEOCEANOGRAPHIC AND PALEOCLIMATIC SIGNATURE OF THE CRETACEOUS/PALEOGENE BOUNDARY IN THE ANTARCTIC: STABLE ISOTOPIC RESULTS FROM ODP LEG 113 ${ }^{1}$
}

\author{
Lowell D. Stott ${ }^{2}$ and James P. Kennett ${ }^{3}$
}

\begin{abstract}
Stable isotopic records across the Cretaceous/Paleogene (K/P) boundary in Maud Rise Holes 689B and 690C indicate that significant climatic changes occurred during the latest Cretaceous, beginning approximately $500 \mathrm{k} . \mathrm{y}$. prior to the mass extinction event and the enrichment of iridium at the K/P boundary $(66.4 \mathrm{Ma})$. An oxygen isotopic decrease of $\sim 0.7 \%_{0} \sim 1.0 \%$ is recorded in the Late Cretaceous planktonic and benthic foraminifers between 66.9 and $66.6 \mathrm{Ma}$. The negative isotope excursion was followed by a positive excursion of similar magnitude between 66.6 Ma (latest Cretaceous) and $\sim 66.3 \mathrm{Ma}$ (earliest Paleocene). No other isotopic excursions of this magnitude are recorded in the planktonic and benthic microfossil records $1.0 \mathrm{~m} . \mathrm{y}$ prior to, and for $2.0 \mathrm{~m}$.y following the mass extinction event at the K/P boundary. The magnitude and duration of these isotopic excursions were similar to those at the Paleocene/Eocene and Eocene/Oligocene boundaries.

A major $\delta^{13} \mathrm{C}$ excursion occurred $200 \mathrm{k}$.y. prior to the boundary, involving a positive shift in planktonic and benthic $\delta^{13} \mathrm{C}$ of $\sim 0.5 \% 0-0.75 \%$. Similar changes observed in other deep-sea sequences indicate that this reflected a global change in $\delta^{13} \mathrm{C}$ of the oceanic total dissolved carbon (TDC) reservoir. The magnitude of this inferred carbon reservoir change and its association with high latitude surface-water temperature changes recorded in the $\delta^{18} \mathrm{O}$ records implies that it was linked to global climate change through feedback loops in the carbon cycle.

At the $\mathrm{K} / \mathrm{P}$ boundary, the surface-to-deep water $\delta^{13} \mathrm{C}$ gradient is reduced by approximately $0.6 \% 0^{-} \sim 0.2 \% 0_{0}$. However, unlike sequences elsewhere, the planktonic-benthic $\delta^{13} \mathrm{C}$ gradient $\left(\Delta \delta^{13} \mathrm{C}\right)$ was not eliminated in the Antarctic. The surface-to-deep water gradient was re-established gradually during the $400 \mathrm{k}$.y. following the mass extinction. Full recovery of the $\Delta \delta^{13} \mathrm{C}$ occurred by $\sim 60.0 \mathrm{Ma}$. In addition to the reduced vertical $\delta^{13} \mathrm{C}$ gradient across the $\mathrm{K} / \mathrm{P}$ boundary, there was a negative excursion in both planktonic and benthic $\delta^{13} \mathrm{C}$ beginning approximately $100 \mathrm{k} . \mathrm{y}$. after the boundary $(66.3$ Ma). This excursion resulted in benthic $\delta^{13} \mathrm{C}$ values in the early Paleogene that were similar to those in the pre- $\mathrm{K} / \mathrm{P}$ boundary intervals. This negative shift appears to reflect a change in the $\delta^{13} \mathrm{C}$ of the oceanic TDC reservoir shift that may have resulted from reduced carbon burial and/or increased carbon flux to the oceans.

Any model that attempts to explain the demise of the oceanic plankton at the end of the Cretaceous should consider the oceanic environmental changes that were occurring prior to the massive extinction event.
\end{abstract}

\section{INTRODUCTION}

Prior to the drilling of Leg 113, continuous and well preserved carbonate sequences had never been recovered from the Antarctic. Thus, the Antarctic component was missing in paleoreconstructions of circulation, climate, and nutrient cycling in the global ocean during the Late Cretaceous to early Paleogene. Upper Cretaceous to early Paleogene sequences were recovered in Holes 689B and 690C, drilled in 2080 and $2914 \mathrm{~m}$ of water respectively. Together, these two sequences provide a nearly continuous stratigraphic/paleoceanographic record across the Cretaceous/Paleogene (K/P) boundary in the Antarctic.

The data presented here represent the first results of continuous stable isotopic analyses carried out on monospecific and monogeneric foraminiferal samples from both Maud Rise sequences. Concentrated calcareous nannofossil samples were also analyzed from Hole 690C. Oxygen isotope results provide information about surface and deep water temperatures during the latest Cretaceous to early Paleocene. Carbon isotope results are interpreted in terms of organic carbon/nutrient distributions in the surface and deep waters of the Antarctic and the global ocean, as well as terrestrial reservoirs. The Antarctic isotopic re-

\footnotetext{
${ }^{1}$ Barker, P. F., Kennett, J. P., et al., 1990. Proc. ODP, Sci. Results, 113: College Station, TX (Ocean Drilling Program).

2 Department of Geological Sciences, University of Southern California, Los Angeles, CA 90089.

${ }_{3}$ Marine Science Institute and Department of Geological Sciences, University of California Santa Barbara, Santa Barbara, CA 90136.
}

sults presented here are also compared with those elsewhere to better understand global paleoceanographic/paleoclimatic conditions during the $\mathrm{K} / \mathrm{P}$ transition.

\section{METHODS}

Sediment samples from Holes $689 \mathrm{~B}$ and $690 \mathrm{C}$ were dried at $50^{\circ} \mathrm{C}$ and weighed before being disaggregated in a solution of distilled water and sodium hexametaphosphate. All samples from Hole $690 \mathrm{C}$ disaggregated readily. A number of samples from chalky intervals, in Hole 689B, required longer soaking times (up to $48 \mathrm{hr}$ ), to fully disaggregate the sediment. Disaggregated sediment was washed in distilled water over a $63 \mu \mathrm{m}$ screen and dried in an oven at $50^{\circ} \mathrm{C}$. The sediment fraction finer than 63 $\mu \mathrm{m}$ was caught on filter paper and dried at $50^{\circ} \mathrm{C}$. The larger size fraction was then reweighed. Planktonic and benthic foraminifers were picked from the $>63 \mu \mathrm{m}$ size fraction for stable isotope analysis following biostratigraphic evaluation (Stott and Kennett, this volume, chapter 34). Monogeneric benthic foraminiferal samples were obtained of Cibicidoides, Gavelinella, Nuttallides, and Osangularia. The Cretaceous planktonic foraminifers Globigerinelloides multispinatus (Lalicker) and Heterohelix globulosa (Ehrenberg) were picked from the $150-250 \mu \mathrm{m}$ size fraction. These species occur in samples above the K/P boundary and were picked from several of these Paleocene samples in order to evaluate whether they were reworked across the boundary or may have survived into the Cenozoic, based on their isotopic compositions. The Paleogene planktonic foraminifers Eoglobigerina fringa (Hofker) and Subbotina pseudobulloides (Plummer) were picked from the $>63 \mu \mathrm{m}$ fraction. All foraminiferal 
samples were ultrasonically cleaned in methanol for $5 \mathrm{~s}$ to remove adhering calcareous nannofossils. Fine-fraction samples, consisting primarily of calcareous nannofossils were prepared for isotopic analysis by taking aliquots of the $<63 \mu \mathrm{m}$ fraction and washing in distilled water. Following the procedure of Margolis et al. (1975), these samples were then centrifuged for $2 \mathrm{~min}$ at $\sim 2000 \mathrm{rpm}$ to separate the calcareous nannofossils from small planktonic and benthic foraminifers. This procedure results in concentrates of calcareous nannofossils (Margolis et al., 1975). Between 100 and $300 \mu \mathrm{g}$ of the fine-fraction material was sampled from the top of the centrifuged sediment below a clay layer. These were placed in sample boats and dried at $50^{\circ} \mathrm{C}$.

Isotopic analyses were carried out at the University of California, Santa Barbara (UCSB) using a Finnigan MAT 251 mass spectrometer linked to a Carousel-48 automatic carbonate preparation device. Benthic and planktonic samples were analyzed separately using ortho-phosphoric acid $\left(\mathrm{H}_{3} \mathrm{PO}_{4}\right)$, which was renewed after every 20-25 samples. Benthic foraminifers were reacted at $90^{\circ} \mathrm{C}$ for $12 \mathrm{~min}$; planktonic samples were reacted at the same temperature for $7 \mathrm{~min}$. All isotopic data are reported in $\%_{0}$ notation relative to the PDB standard. The UCSB laboratory gas standard is calibrated to PDB by cross-calibration using NBS-20. Analytical precision of consecutive runs of our laboratory standards (NBS 20 and Ultis) average $0.07 \%$ for $\delta^{18} \mathrm{O}$ and $0.05 \%$ for $\delta^{13} \mathrm{C}$. Practical precision, based on the reproducibility of laboratory standards analyzed during the automated runs of the autopreparation device, were $0.1 \%$ for $\delta^{18} \mathrm{O}$ and $0.07 \%$ for $\delta^{13} \mathrm{C}$. Replicate analyses were also carried out for a number of planktonic and benthic samples. To minimize potential systematic error, samples were run in a random order with no regard to stratigraphic position. The reproducibility of the results are illustrated and discussed in the following sections. Isotopic results are presented in Table 1.

Trace metal (Sr, Mn, Ca) composition for benthic foraminiferal samples were determined by Dr. Margaret Delaney at the University of California, Santa Cruz, using flame and flameless atomic absorption spectrophotometry. Benthic foraminifers were reductively cleaned following the methods of Boyle (1981) and Boyle and Keigwin (1986). Analytical precision based on replicate analyses of benthic foraminifers from the same horizons was $5 \%$ or better. Results are reported as ratios of $\mathrm{Sr}$ to $\mathrm{Ca}$ and $\mathrm{Mn}$ to $\mathrm{Ca}$.

\section{PRESERVATION}

The ooze/chalk transition is gradational in both sites. Chalk first occurs as thin $2-3 \mathrm{~cm}$ thick horizons at $\sim 190 \mathrm{mbsf}$ (meters below seafloor) in Hole 689B, and at $\sim 204$ mbsf in Hole 690C. The chalk increases in abundance downward as thin horizons within a dominantly calcareous ooze. Chalk occurs exclusively below $236 \mathrm{mbsf}$ in Hole 689B and 233 mbsf in Hole 690C (Barker, Kennett, et al., 1988). We examined each stable isotope sample for evidence of recrystallization using standard light microscopy. Several benthic and planktonic specimens from various horizons were also examined using scanning electron microscopy. Preservation of calcareous nannofossils is discussed by Pospichal and Wise (this volume, chapter 32 ).

There are no visible signs of calcium carbonate recrystallization in the benthic and planktonic foraminifer specimens examined from Hole 690C. Preservation is generally good. Several benthic specimens did, however, exhibit small overgrowths on the inner chamber walls (Pl. 1) that may represent manganese carbonate overgrowths. Boyle (1983) has pointed out that, in cases of extensive crystallization, these overgrowths represent only $0.1 \%$ of the total foraminiferal carbonate and, therefore, have little effect on oxygen isotopic values. Manganese and other trace metal concentrations were monitored during stepwise dissolutions of reductively cleaned benthic foraminiferal samples
(Table 2; Delaney and Stott, in prep.). These analyses showed no significant variation with increasing dissolution. This further indicates that these overgrowths form only a small veneer on the inner chamber walls and do not contribute significantly to the isotope chemistry of the biogenic samples. $\mathrm{Sr} / \mathrm{Ca}$ ratios are similar to well preserved samples from shallower, well-preserved Quaternary horizons (Table 2). Dissolution has affected some of the less calcified planktonic foraminifers within the lowermost Paleogene, as shown by increases in test fragmentation and pore size. We attribute this to a shallow lysocline during the early $\mathrm{Pa}-$ leogene interval and not to post-depositional diagenesis. We consider all the benthic and planktonic foraminifer samples analyzed from Hole $690 \mathrm{C}$ to be well preserved. Some specimens examined with the SEM had nannofossils coating the inner walls of chambers. This contributes only a small percentage of the total carbonate in a benthic isotope sample and does not significantly effect the isotope values. An example of the preservational quality of the benthic and planktonic foraminifers analyzed from the $\mathrm{K} / \mathrm{P}$ boundary intervals of Hole $690 \mathrm{C}$ are shown in Plates 1 and 2.

The benthic foraminifers examined from Hole 689B do not appear to be recrystallized, although some samples were chalky and did not disaggregate readily. There is also evidence of testwall dissolution in some specimens, although it is not clear if this represents pre- or post-depositional dissolution. Visual examinations indicate that benthic foraminifers from Hole 689B show similar preservation to those of Hole $690 \mathrm{C}$.

\section{CARBONATE ACCUMULATION RATES}

Carbonate percentages were determined by weighing a small (0.1-0.2 g) dried sample that was dissolved in $10 \%$ acetic acid, the residue centrifuged, and the supernatant decanted off. The remaining insoluble residue was washed in distilled water, centrifuged, and then washed again in methanol. The residue was then transferred to plastic weighing trays, dried, and reweighed. Carbonate percentage was calculated on a wt $\%$ basis by calculating the difference between the first and second weighing. Percent carbonate determined in this way agrees closely with values determined by automated titration (O'Connell, this volume, chapter 6). Carbonate accumulation rates (CAR) were calculated using the equation:

$$
\mathrm{CAR}=\mathrm{S}\left(\mathrm{W}-(\mathrm{P} / 100)\left(1.01 \mathrm{~g} / \mathrm{cm}^{3}\right)\right)\left(\mathrm{wt} \% \mathrm{CaCO}_{3}\right)
$$

where $\mathrm{S}=$ sedimentation rate $(\mathrm{cm} / \mathrm{yr}), \mathrm{W}=$ wet bulk density $\left(\mathrm{g} / \mathrm{cm}^{3}\right)$, and $\mathrm{P}=$ porosity. $\mathrm{P}$ and $\mathrm{W}$ were based on shipboard values as described in Barker, Kennett, et al. (1988). In order to preserve sediment material, porosity measurements were not made within the $\mathrm{K} / \mathrm{P}$ boundary intervals. However, this parameter does not differ significantly above or below the K/P boundary interval. We used values from the closest interval where measurements had been made. Sedimentation rates were calculated using the age model described below. A summary of the values is given in Table 3 .

\section{AGE MODEL}

The age models developed for Holes 689B and 690C are based on linear interpolation between magnetobiostratigraphic datum levels. Sedimentation rates were considered to be constant between datum levels. The magnetostratigraphy of Hole $690 \mathrm{C}$ is delineated from the Upper Campanian through the lowermost Paleocene (Hamilton, this volume). The character of the polarity record from Hole $690 \mathrm{C}$ is similar to other published records. However, precise delineation of basal $\mathrm{C} 30 \mathrm{~N}$ and the top of $\mathrm{C} 31 \mathrm{~N}$ is not clear due to poor core recovery and weak magnetic inclinations (Hamilton, this volume). To estimate the age of samples below the $\mathrm{K} / \mathrm{P}$ boundary a linear rate of sedimenta- 
Table 1. Isotopic results (uncorrected values).

\begin{tabular}{|c|c|c|c|c|c|c|c|c|c|c|c|c|c|c|c|}
\hline \multirow[b]{2}{*}{ Hole } & \multirow{2}{*}{$\begin{array}{l}\text { Core, section, } \\
\text { interval }(\mathrm{cm})\end{array}$} & \multirow{2}{*}{$\begin{array}{l}\text { Depth } \\
\text { (mbsf) }\end{array}$} & \multirow{2}{*}{$\begin{array}{l}\text { Age } \\
\text { (Ma) }\end{array}$} & \multicolumn{2}{|c|}{ G. multispinatus } & H. glo & ulosa & E. $f$ & inga & S. pseuc & alloides & A. may & roensis & Fine-f: & iction \\
\hline & & & & $\left(\delta^{18} \mathrm{O}\right)$ & $\left(\delta^{13} \mathrm{C}\right)$ & $\left(\delta^{18} \mathrm{O}\right)$ & $\left(\delta^{13} \mathrm{C}\right)$ & $\left(\delta^{18} \mathrm{O}\right)$ & $\left(\delta^{13} \mathrm{C}\right)$ & $\left(\delta^{18} \mathrm{O}\right)$ & $\left(\delta^{13} \mathrm{C}\right)$ & $\left(\delta^{18} \mathrm{O}\right)$ & $\left(\delta^{13} \mathrm{C}\right)$ & $\left(\delta^{18} O\right)$ & $\left(\delta^{13} \mathrm{C}\right)$ \\
\hline 689B & $25-1,90-92$ & 227.51 & 64.43 & & & & & & & 0.96 & 1.85 & & & & \\
\hline & $25-2,25-28$ & 228.35 & 64.67 & & & & & & & & & & & & \\
\hline & $25-2,45-49$ & 228.55 & 64.73 & & & & & & & & & & & & \\
\hline & $25-2,45-49$ & 228.55 & $\begin{array}{l}64.73 \\
64.77\end{array}$ & & & & & & & & & & & & \\
\hline & $\begin{array}{l}25-2,58-62 \\
25-2,92-94\end{array}$ & 228.68 & $\begin{array}{l}64.77 \\
64.87\end{array}$ & & & & & & & 0.39 & 1.80 & & & & \\
\hline & $\begin{array}{l}25-2,92-94 \\
25-2,129-133\end{array}$ & $\begin{array}{l}229.03 \\
229.39\end{array}$ & $\begin{array}{l}64.87 \\
64.98\end{array}$ & & & & & & & & & & & & \\
\hline & $25-2,129-133$ & 229.39 & 64.98 & & & & & & & & & & & & \\
\hline & $25-3,23-27$ & 229.83 & 65.11 & & & & & & & & & & & & \\
\hline & $25-3,43-46$ & 230.03 & 65.17 & & & & & & & & & & & & \\
\hline & $25-3,60-63$ & 230.20 & 65.22 & & & & & & & 0.89 & 1.84 & & & & \\
\hline & $25-3,91-93$ & 230.52 & 65.31 & & & & & & & & & & & & \\
\hline & $25-3,135-138$ & 230.95 & 65.44 & & & & & & & 0.67 & 1.97 & & & & \\
\hline & $25-4,25-28$ & 231.35 & 65.56 & & & & & & & & & & & & \\
\hline & $25-4,44-47$ & 231.54 & 65.61 & & & & & & & 0.65 & 1.82 & & & & \\
\hline & $25-4,62-66$ & 231.74 & 65.66 & & & & & & & 0.62 & 1.77 & & & & \\
\hline & $25-4,93-95$ & 232.04 & 65.76 & & & & & & & 0.21 & 1.73 & & & & \\
\hline & $25-5,5-7$ & 233.66 & 65.94 & & & & & & & 0.83 & 1.48 & & & & \\
\hline & $25-5,48-50$ & 233.09 & 66.07 & & & & & & & 0.83 & 1.24 & & & & \\
\hline & $25-5,51-53$ & 233.12 & 66.08 & & & & & & & 0.11 & 1.43 & & & & \\
\hline & $25-5,51-53$ & 233.12 & 66.08 & & & & & & & 1.01 & 1.25 & & & & \\
\hline & $25-5,79-81$ & 233.40 & 66.15 & & & & & & & & & & & & \\
\hline & $25-5,79-81$ & 233.40 & 66.15 & & & & & & & & & & & & \\
\hline & $\begin{array}{l}\text { K/P boundary } \\
25-5,91-94\end{array}$ & & & -0.09 & 2.19 & 0.35 & 1.85 & & & & & & & & \\
\hline & $\begin{array}{l}25-5,91-94 \\
25-5,94-96\end{array}$ & 233.51 & $\begin{array}{l}66.53 \\
66.53\end{array}$ & 0.33 & 2.27 & 0.64 & 1.89 & & & & & & & & \\
\hline & $\begin{array}{l}25-5,94-96 \\
25-5,94-96\end{array}$ & $\begin{array}{l}233.54 \\
233.54\end{array}$ & $\begin{array}{l}66.53 \\
66.53\end{array}$ & & & & & & & & & & & & \\
\hline & & & & & & & & & & & & & & & \\
\hline & $25-5,111-113$ & 233.71 & $\begin{array}{l}66.56 \\
66.58\end{array}$ & 0.27 & & 0.39 & $\begin{array}{l}1.82 \\
2.07\end{array}$ & & & & & & & & \\
\hline & $25-5,130-132$ & 233.90 & $\begin{array}{l}66.58 \\
66.63\end{array}$ & 0.29 & $\begin{array}{l}2.35 \\
2.38\end{array}$ & 0.50 & 2.07 & & & & & & & & \\
\hline & $25-6,20-23$ & 234.32 & $\begin{array}{l}66.63 \\
66.67\end{array}$ & & 2.38 & 0.81 & 1.86 & & & & & & & & \\
\hline & $25-6,42-46$ & 234.54 & $\begin{array}{l}66.67 \\
66.73\end{array}$ & & & & & & & & & & & & \\
\hline & $25-6,98-100$ & 235.08 & 66.73 & & & & & & & & & & & & \\
\hline & $26-1,14-16$ & 236.44 & 66.95 & 0.58 & 2.28 & 0.90 & 1.73 & & & & & & & & \\
\hline & $26-1,17-20$ & 236.47 & 66.95 & & & & & & & & & & & & \\
\hline & $26-1,106-108$ & 237.37 & 67.08 & 0.64 & 2.25 & 0.83 & 1.78 & & & & & & & & \\
\hline & $26-1,109-111$ & 237.40 & $\begin{array}{l}67.09 \\
63.17\end{array}$ & & & & & & & 078 & 155 & & & 101 & 237 \\
\hline $690 \mathrm{C}$ & $\begin{array}{l}13-1,110-114 \\
13-1,110-114\end{array}$ & $\begin{array}{l}224.74 \\
224.74\end{array}$ & $\begin{array}{l}63.17 \\
63.17\end{array}$ & & & & & & & 0.10 & 1.00 & & & 1.01 & 2.31 \\
\hline & $13-2,38-42$ & 225.49 & 63.27 & & & & & & & 0.52 & 1.67 & & & & \\
\hline & $13-2,38-40$ & 225.49 & 63.27 & & & & & & & & & & & & \\
\hline & $13-2,104-108$ & 226.16 & 63.36 & & & & & & & & & & & 0.14 & 2.39 \\
\hline & $13-2,104-108$ & 226.16 & 63.36 & & & & & & & & & & & & \\
\hline & $13-3,36-40$ & 226.98 & 63.44 & & & & & & & 0.66 & 1.72 & & & & \\
\hline & $13-3,109-113$ & 227.72 & 63.51 & & & & & & & & & & & 0.52 & 2.60 \\
\hline & $13-3,109-113$ & 227.72 & 63.56 & & & & & & & & & & & & \\
\hline & $13-4,40-44$ & 228.47 & 63.66 & & & & & & & & & & & & \\
\hline & $13-4,110-114$ & 229.22 & 63.76 & & & & & & & 0.31 & 1.36 & & & 0.05 & 2.83 \\
\hline & $13-5,40-44$ & 230.02 & 63.86 & & & & & & & & & & & 0.91 & 2.68 \\
\hline & $13-5,110-115$ & 230.72 & 63.95 & & & & & & & & & & & 0.11 & 2.86 \\
\hline & $13-5,110-115$ & 230.72 & 63.95 & & & & & & & & & & & 0.67 & 2.65 \\
\hline & $13-6,36-40$ & 231.48 & 64.05 & & & & & & & 0.66 & 1.77 & & & 0.41 & 2.63 \\
\hline & $13-6,36-40$ & 231.48 & 64.05 & & & & & & & & & & & 0.42 & 2.49 \\
\hline & $13-6,110-114$ & 232.22 & 64.14 & & & & & & & & & & & & \\
\hline & $13-6,110-114$ & 232.22 & 64.14 & & & & & & & & & & & -0.19 & 2.36 \\
\hline & $13-6,110-114$ & 232.22 & 64.14 & & & & & & & & & & & 0.58 & 2.48 \\
\hline & $13, \mathrm{CC}$ & 233.20 & 64.21 & & & & & & & & & & & & \\
\hline & $14-1,36-40$ & 233.58 & 64.32 & & & & & & & 0.53 & 1.86 & & & -0.12 & 1.90 \\
\hline & $14-1,36-40$ & 233.58 & 64.32 & & & & & & & & & & & 0.37 & 2.63 \\
\hline & $14-1,110-114$ & 234.32 & 64.42 & & & & & & & & & & & 0.09 & 2.16 \\
\hline & $14-1,110-114$ & 234.32 & 64.42 & & & & & & & & & & & 0.35 & 2.66 \\
\hline & $14-2,36-40$ & 235.08 & 64.52 & & & & & & & 0.52 & 1.74 & & & 0.48 & 2.64 \\
\hline & $14-2,36-40$ & 235.08 & 64.52 & & & & & & & & & & & 0.62 & 2.62 \\
\hline & $14-2,110-114$ & 235.82 & 64.61 & & & & & & & 0.57 & 1.83 & & & 0.21 & 2.30 \\
\hline & $14-2,110-114$ & 235.82 & 64.61 & & & & & & & & & & & 0.00 & 2.39 \\
\hline & $14-3,36-40$ & 236.58 & 64.71 & & & & & & & 0.57 & 2.05 & & & 0.07 & 2.76 \\
\hline & $14-3,36-40$ & 236.58 & 64.71 & & & & & & & & & & & 0.66 & 2.74 \\
\hline & $14-3,110-114$ & 237.32 & 64.81 & & & & & & & & & & & 0.60 & 2.67 \\
\hline & $14-3,110-114$ & 237.32 & 64.81 & & & & & & & & & & & 0.43 & 2.77 \\
\hline & 14, CC & 242.90 & 65.53 & & & & & & & 0.50 & 1.99 & & & 0.54 & 3.04 \\
\hline & $14, \mathrm{CC}$ & 242.90 & 65.53 & & & & & & & & & & & & \\
\hline & $14, \mathrm{CC}$ & 242.90 & 65.53 & & & & & & & & & & & & \\
\hline & $15-1,3-5$ & 242.94 & 65.54 & & & & & & & & & & & & \\
\hline
\end{tabular}


Table 1 (continued).

\begin{tabular}{|c|c|c|c|c|c|c|c|c|c|c|c|c|c|c|c|}
\hline \multirow[b]{2}{*}{ Hole } & \multirow{2}{*}{$\begin{array}{l}\text { Core, section, } \\
\text { interval (cm) }\end{array}$} & \multirow{2}{*}{$\begin{array}{l}\text { Depth } \\
\text { (mbsf) }\end{array}$} & \multirow{2}{*}{$\begin{array}{l}\text { Age } \\
\text { (Ma) }\end{array}$} & G. mult & pinatus & H. glc & ulosa & E. $f$ & inga & S. pseud & ulloides & A. may & roensis & Fine-f & ction \\
\hline & & & & $\left(\delta^{18} \mathrm{O}\right)$ & $\left(\delta^{13} \mathrm{C}\right)$ & $\left(\delta^{18} \mathrm{O}\right)$ & $\left(\delta^{13} \mathrm{C}\right)$ & $\left(\delta^{18} \mathrm{O}\right)$ & $\left(\delta^{13} \mathrm{C}\right)$ & $\left(\delta^{18} \mathrm{O}\right)$ & $\left(\delta^{13} \mathrm{C}\right)$ & $\left(\delta^{18} \mathrm{O}\right)$ & $\left(\delta^{13} \mathrm{C}\right)$ & $\left(\delta^{18} \mathrm{O}\right)$ & $\left(\delta^{13} \mathrm{C}\right)$ \\
\hline $689 \mathrm{C}$ & & & & & & & & & & & & & & & \\
\hline & $15-1,3-5$ & 242.94 & 65.54 & & & & & & & & & & & 0.59 & 2.82 \\
\hline & $15-1,92-94$ & 243.83 & 65.65 & & & & & & & 0.54 & 2.07 & & & & \\
\hline & $15-1,92-94$ & 243.83 & 65.65 & & & & & & & 0.59 & 2.01 & & & & \\
\hline & $15-2,5-7$ & 244.48 & 65.74 & & & & & & & & & & & & \\
\hline & $15-2,21-25$ & 244.64 & 65.76 & & & & & & & 0.49 & 2.02 & & & & \\
\hline & $15-2,46-50$ & 244.88 & 65.79 & & & & & & & & & & & & \\
\hline & $15-2,46-50$ & 244.88 & 65.79 & & & & & & & & & & & & \\
\hline & $15-2,94-96$ & 245.35 & 65.85 & & & & & & & 0.59 & 2.22 & & & 0.18 & 2.66 \\
\hline & $15-2,132-136$ & 245.74 & 65.88 & & & & & & & & & & & & \\
\hline & $15-2,132-136$ & 245.74 & 65.88 & & & & & & & & & & & & \\
\hline & $15-2,132-136$ & 245.74 & 65.88 & & & & & & & & & & & & \\
\hline & $15-2,132-136$ & 245.74 & 65.88 & & & & & & & & & & & & \\
\hline & $15-3,8-10$ & 245.99 & 65.93 & & & & & & & & & & & & \\
\hline & $15-3,8-10$ & 245.99 & 65.93 & & & & & & & & & & & & \\
\hline & $15-3,25-29$ & 246.17 & 65.96 & & & & & & & & & & & & \\
\hline & $15-3,25-29$ & 246.17 & 65.96 & & & & & & & 0.68 & 1.98 & & & & \\
\hline & $15-3,41-46$ & 246.32 & 65.98 & & & & & & & & & & & & \\
\hline & $15-3,41-46$ & 246.32 & 65.98 & & & & & & & & & & & & \\
\hline & $15-3,95-97$ & 246.86 & 66.05 & & & & & & & 0.45 & 1.68 & & & -0.15 & 2.02 \\
\hline & $15-3,95-97$ & 246.86 & 66.05 & & & & & & & & & & & 0.07 & 2.25 \\
\hline & $15-3,132-137$ & 247.24 & 66.10 & & & & & & & & & & & -0.28 & 1.31 \\
\hline & $15-3,132-136$ & 247.24 & 66.10 & 0.53 & 2.92 & & & & & 0.61 & 1.93 & & & -0.31 & 1.29 \\
\hline & $15-4,6-8$ & 247.46 & 66.17 & 0.35 & 2.67 & & & & & & & & & & \\
\hline & $15-4,28-30$ & 247.69 & 66.31 & & & & & 0.82 & 2.47 & & & & & 0.39 & 2.10 \\
\hline & $15-4,28-30$ & 247.69 & 66.31 & 0.36 & 2.79 & & & 1.13 & 2.42 & & & & & 0.52 & 2.02 \\
\hline & $15-4,35-37$ & 247.76 & 66.36 & & & & & 0.78 & 2.31 & & & & & -0.15 & 2.41 \\
\hline & $15-4,35-37$ & 247.76 & 66.36 & 0.22 & 2.86 & & & 0.65 & 2.46 & & & & & -0.17 & 2.40 \\
\hline & $\mathrm{K} / \mathrm{P}$ boundary & 247.82 & 66.40 & & & & & & & & & & & & \\
\hline & $15-4,45-47$ & 247.86 & 66.40 & 0.28 & 2.84 & & & & & & & & & & \\
\hline & $15-4,45-47$ & 247.86 & 66.40 & 0.25 & 2.83 & 0.71 & 2.33 & & & & & & & 0.25 & 2.75 \\
\hline & $15-4,57-59$ & 247.98 & 66.42 & & & & & & & & & & & 0.31 & 2.84 \\
\hline & $15-4,57-59$ & 247.98 & 66.42 & 0.23 & 2.99 & & & & & & & & & & \\
\hline & $15-4,57-59$ & 247.98 & 66.42 & & & 0.75 & 2.42 & & & & & & & & \\
\hline & $15-4,57-59$ & 247.98 & 66.42 & 0.31 & 2.89 & & & & & & & & & 0.25 & 2.80 \\
\hline & $15-4,84-86$ & 248.25 & 66.44 & 0.25 & 2.87 & 0.70 & 2.28 & & & & & & & & \\
\hline & $15-4,84-86$ & 248.25 & 66.44 & 0.36 & 2.81 & & & & & & & & & 0.44 & 2.84 \\
\hline & $15-4,84-86$ & 248.25 & 66.44 & & & & & & & & & & & & \\
\hline & $15-4,106-108$ & 248.47 & 66.46 & & & & & & & & & & & 0.14 & 2.83 \\
\hline & $15-4,106-108$ & 248.47 & 66.46 & & & & & & & & & & & & \\
\hline & $15-4,106-109$ & 248.47 & 66.46 & 0.25 & 2.88 & & & & & & & & & 0.21 & 2.68 \\
\hline & $15-4,146-148$ & 248.87 & 66.50 & 0.12 & 2.73 & & & & & & & & & -0.07 & 2.81 \\
\hline & $15-4,146-148$ & 248.87 & 66.50 & & & & & & & & & 0.29 & 2.16 & -0.12 & 2.59 \\
\hline & $15-4,146-148$ & 248.87 & 66.50 & & & & & & & & & & & -0.23 & 2.55 \\
\hline & $15-4,146-148$ & 248.87 & 66.50 & & & & & & & & & & & & \\
\hline & $15-5,4-7$ & 248.96 & 66.51 & & & & & & & & & & & & \\
\hline & $15-5,25-28$ & 249.16 & 66.52 & -0.08 & 2.84 & 0.60 & 2.25 & & & & & & & & \\
\hline & $15-5,68-70$ & 249.58 & 66.56 & & & & & & & & & & & & \\
\hline & $15-5,76-78$ & 249.67 & 66.57 & -0.06 & 2.75 & & & & & & & 0.02 & 2.19 & -0.28 & 2.73 \\
\hline & $15-5,76-78$ & 249.67 & 66.57 & & & 0.55 & 2.22 & & & & & & & -0.29 & 2.35 \\
\hline & $15-5,76-78$ & 249.67 & 66.57 & -0.02 & 2.61 & & & & & & & & & -0.44 & 2.38 \\
\hline & $15-5,104-107$ & 250.27 & 66.63 & & & & & & & & & & & & \\
\hline & $15-5,110-113$ & 250.33 & 66.63 & -0.09 & 2.58 & & & & & & & & & & \\
\hline & $15-6,5-7$ & 250.47 & 66.65 & -0.09 & 2.47 & & & & & & & & & & \\
\hline & $15-6,5-7$ & 250.47 & 66.65 & -0.19 & 2.50 & & & & & & & & & & \\
\hline & $15-6,24-27$ & 250.67 & 66.66 & -0.01 & 2.50 & 0.45 & 2.30 & & & & & & & & \\
\hline & $15-6,45-49$ & 250.87 & 66.68 & -0.07 & 2.56 & & & & & & & & & & \\
\hline & $15-6,96-98$ & 251.37 & 66.73 & 0.36 & 2.76 & & & & & & & & & & \\
\hline & $15-6,96-98$ & 251.37 & 66.73 & & & & & & & & & 0.22 & 2.73 & -0.88 & 3.12 \\
\hline & $15-6,96-98$ & 251.37 & 66.73 & & & & & & & & & & & -0.64 & 2.40 \\
\hline & $15-6,96-98$ & 251.37 & 66.73 & & & & & & & & & & & -1.10 & 2.64 \\
\hline & $15-7,6-8$ & 251.97 & 66.80 & & & & & & & & & & & & \\
\hline & $15-7,6-8$ & 251.97 & 66.80 & 0.39 & 2.66 & 0.83 & 2.18 & & & & & & & & \\
\hline & $15, \mathrm{CC}$ & 252.50 & 66.87 & & & & & & & & & 0.30 & 2.47 & -0.44 & 2.80 \\
\hline & $15, \mathrm{CC}$ & 252.50 & 66.87 & & & & & & & & & & & & \\
\hline & $15, \mathrm{CC}$ & 252.50 & 66.87 & & & & & & & & & & & -0.80 & 2.00 \\
\hline & $16-2,40-42$ & 254.41 & 67.11 & 0.34 & 2.76 & 0.65 & 2.14 & & & & & & & & \\
\hline & $16-2,114-116$ & 255.16 & 67.20 & 0.39 & 2.77 & 0.69 & 2.06 & & & & & & & & \\
\hline & $16-3,40-42$ & 255.91 & 67.30 & 0.33 & 2.74 & 0.85 & 2.21 & & & & & & & & \\
\hline & $16-4,39-41$ & 257.40 & 67.40 & 0.49 & 2.67 & 0.84 & 2.12 & & & & & & & & \\
\hline & $16, \mathrm{CC}$ & 261.80 & 68.04 & 0.26 & 2.28 & & & & & & & 0.35 & 2.90 & & \\
\hline & $16, \mathrm{CC}$ & 261.80 & 68.04 & 0.52 & 2.68 & & & & & & & & & & \\
\hline
\end{tabular}


Table 2. Trace metal results.

\begin{tabular}{llcc}
\hline Hole & $\begin{array}{l}\text { Core, section, } \\
\text { interval }(\mathrm{cm})\end{array}$ & $\begin{array}{c}\mathrm{Sr} / \mathrm{Ca} \\
\left(10^{-3}\right)\end{array}$ & $\begin{array}{c}\mathrm{Mn} / \mathrm{Ca} \\
\left(10^{-6}\right)\end{array}$ \\
\hline $690 \mathrm{C}$ & $14, \mathrm{CC}$ & 1.21 & 128 \\
& $15-3,95-97$ & 1.04 & 269 \\
& $15-4,28-30$ & 1.25 & 262 \\
& $15-4,45-47$ & 1.41 & 210 \\
& $15-4,84-87$ & 1.36 & 154 \\
& $15-4,106-108$ & 1.44 & 135 \\
& $15, \mathrm{CC}$ & 1.32 & 108 \\
& $16, \mathrm{CC}$ & 1.27 & 143
\end{tabular}

Partial dissolution steps

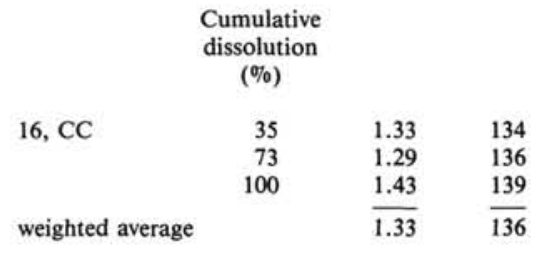

tion was assumed for intervals between the top of $\mathrm{C} 30 \mathrm{~N}$ and the base of $\mathrm{C} 31 \mathrm{~N}$. The K/P boundary, recognized on the basis of extinctions of Cretaceous planktonic foraminifers (Stott and Kennett, this volume, chapter 34) and calcareous nannofossil species (Pospichal and Wise, this volume, chapter 32) occurs near the top of a reversed polarity zone correlated to Chron 29R. The K/P boundary occurs near the Chron $29 \mathrm{R} / 29 \mathrm{~N}$ boundary. The thickness of the reversed interval above the $\mathrm{K} / \mathrm{P}$ boundary at this site appears to be thinner than that observed in other sections (see discussion by Hamilton, this volume). This is either due to the condensed nature of this interval or because some of the earliest Paleocene is missing in a biostratigraphically unrecognizable hiatus. The boundary is marked by a distinct color change within Section 113-690C-15X-4, between 247.75 and 247.80 mbsf (Stott and Kennett, this volume, chapter 34; Pospichal and Wise, this volume, chapter 32). The boundary itself is marked by an iridium anomaly, centered at $247.82 \mathrm{mbsf}$ (Michel et al., this volume). Berggren et al. (1985) have assigned the Cretaceous/Paleogene boundary, in marine sections, a magnetostratigraphic age of $66.4 \mathrm{Ma}$., the age followed here. The base of Chron 29N occurs between Samples 113-690C-15X-4, 21-23 $\mathrm{cm}$, and $-5 \mathrm{X}-3,147-149 \mathrm{~cm}$, at $247.49 \mathrm{mbsf}$, or $0.33 \mathrm{~m}$ above the iridium anomaly. The magnetostratigraphy between the base of Chron $29 \mathrm{~N}$ and the top of Core 113-690C-11X is not clear. This portion of the core exhibits normal polarity with only slight variations in inclination (Hamilton, this volume). Although the standard magnetostratigraphic record for this interval (Berggren et al., 1985) contains several distinct reversals, these could not be identified in Hole $690 \mathrm{C}$ and hence, we have used biochronology in this part of the sequence.

The planktonic foraminiferal biostratigraphy of Holes 689B and $690 \mathrm{C}$ is described by Stott and Kennett (this volume, chapter 34). Several planktonic foraminiferal datum levels observed in Holes 689B and 690C have previously been integrated with magnetochronostratigraphy in South Atlantic deep-sea sites (Poore et al., 1983; Berggren et al., 1985). These include the first appearance of Subbotina pseudobulloides $(66.1 \mathrm{Ma})$ and the last appearance of Globoconusa daubjergensis (66.4 Ma). The stratigraphic occurrence of these datum levels in the Maud Rise sequences is discussed by Stott and Kennett (this volume, chapter 34).

Hole 689B lacks good magnetostratigraphy in the $\mathrm{K} / \mathrm{P}$ boundary interval. At this site, the age model is based on biochronol- ogy and stable isotope stratigraphy correlated directly to Hole 690C. In the uppermost Cretaceous of both Maud Rise sites, planktonic and benthic foraminifers exhibit a marked negative excursion in $\delta^{18} \mathrm{O}$. In Hole $690 \mathrm{C}$ the excursion occurs near the base of Chron 29R. At this site, oxygen isotope values are $\sim-0.1 \%$ (uncorrected value), about $3 \mathrm{~m}$ below the iridium anomaly (Fig. 1), in an interval with an assigned age of 66.566.6 Ma (Table 1). A similar negative excursion occurs in Hole 689B at 233.5 mbsf (Fig. 2) and is assigned an age of $66.53 \mathrm{Ma}$. The Abathomphalus mayaroensis Zone occurs at $256.4 \mathrm{mbsf}$ (Huber, this volume), where it is assigned a biochronologic age of $69.39 \mathrm{Ma}$. Between this datum level and the isotopic level described above, ages were calculated by extrapolating a linear sedimentation rate of $8.0 \mathrm{~m} / \mathrm{m}$.y.

Biostratigraphic evidence and the absence of any iridium anomaly (Michel et al., this volume; Stott and Kennett, this volume, chapter 34; Pospichal and Wise, this volume, chapter 32) indicate that the $\mathrm{K} / \mathrm{P}$ boundary interval in Hole $689 \mathrm{~B}$ is not continuous. Pospichal and Wise (this volume, chapter 32) did not recognize any of the lowest Paleocene calcareous nannofossil CP1a Zone in Hole 689B, whereas Stott and Kennett (this volume, chapter 34) did recognize some of Zone AP $\alpha$, the lowermost Paleocene planktonic foraminifer zone. The top of the $\mathrm{CP} 1 \mathrm{a}$ Zone has an age of $66.0 \mathrm{Ma}$; the top of the AP $\alpha$ Zone an age of 66.1 Ma. This suggests that one or both of the biostratigraphic zonations needs to be adjusted for the Hole 689B sequence. For the purposes of this paper we have estimated the duration of the Hole 689B hiatus by correlating the isotopic record of this site directly to that of Hole $690 \mathrm{C}$, inferring that the latter sequence is complete. In Hole 690 C the isotope record of both benthic and planktonic foraminifers exhibit a marked positive $\delta^{18} \mathrm{O}$ shift immediately preceding the boundary (Fig. 1). This positive shift begins $1.5 \mathrm{~m}$ below the iridium anomaly and continues to the boundary. This positive excursion does not occur in the uppermost Cretaceous of Hole 689B. In fact, the contact between the Cretaceous and Paleogene, based on the extinction of Cretaceous planktonic foraminifers and calcareous nannofossil species coincides with the negative $\delta^{18} \mathrm{O}$ excursion discussed earlier (Fig. 2). Based on the chronology of Hole 690C we estimate that $0.17 \mathrm{~m} . \mathrm{y}$. is missing from the uppermost Cretaceous of Hole 689B.

To estimate the age of the lowermost Paleocene sample in Hole $689 \mathrm{~B}$ we correlated benthic $\delta^{13} \mathrm{C}$ values to those of Hole 690C. Above the Cretaceous/Paleogene contact in Hole 689B, planktonic foraminiferal assemblages are assigned to Zone AP $\alpha$ as discussed above. In Hole $690 \mathrm{C}$, Gavelinella $\delta^{13} \mathrm{C}$ values decreased from $2.2 \%$ at the $\mathrm{K} / \mathrm{P}$ boundary to $1.6 \%, \sim 40 \mathrm{~cm}$ above the boundary (Fig. 3). In Hole 689B, the lowermost $\mathrm{Pa}$ leocene ( $233.40 \mathrm{mbsf}$ ) Gavelinella $\delta^{13} \mathrm{C}$ values are $\sim 1.6 \%$, similar to those observed at $40 \mathrm{~cm}$ above the boundary in Hole 690C at an estimated age of $66.17 \mathrm{Ma}$. A similar age of $66.15 \mathrm{Ma}$ is therefore assigned to the lowermost Paleocene sample in Hole 689B.

Stott and Kennett (this volume, chapter 34) recorded the first common occurrence of $S$. pseudobulloides in Hole 689B between Samples 113-689B-25X-4, 93-95 cm, and -25X-4, 62-66 $\mathrm{cm}$ (Stott and Kennett, this volume, chapter 34 ). However, because the utility of this horizon in Hole 689B (datum level for the top of the $\operatorname{AP} \alpha$ Zone) is uncertain, as discussed earlier, we have chosen to calculate ages by extrapolating a linear rate of sedimentation between the Subbotina inconstans FAD (top of AP1a Zone; $65.1 \mathrm{Ma}$ ) at $229.8 \mathrm{mbsf}$ and the isotopic datum level discussed above at $233.4 \mathrm{mbsf}$. This implies a sedimentation rate of $3.4 \mathrm{~m} / \mathrm{m}$.y. between these two datum levels. Above the base of the APla Zone the remainder of the lower Paleocene is abbreviated in Hole 689B due to poor core recovery and 
Table 3. Carbonate and insoluble accumulation rates for Holes $689 \mathrm{~B}$ and $690 \mathrm{C}$.

\begin{tabular}{|c|c|c|c|c|c|c|}
\hline Hole & $\begin{array}{l}\text { Core, section, } \\
\text { interval }(\mathrm{cm})\end{array}$ & $\begin{array}{l}\text { Insolubles } \\
\text { (wt \%) }\end{array}$ & $\begin{array}{c}\text { Carbonate } \\
(w t \%)\end{array}$ & $\begin{array}{l}\% \text { Carbonate } \\
\text { titration }\end{array}$ & $\begin{array}{l}\text { Carbonate } \\
\text { accumulation rate } \\
\left(\mathrm{g} / \mathrm{cm}^{2} / \mathrm{k} . \mathrm{y} .\right)\end{array}$ & $\begin{array}{l}\text { Insoluble } \\
\text { accumulation rate } \\
\left(\mathrm{g} / \mathrm{cm}^{2} / \mathrm{k} . \mathrm{y} .\right)\end{array}$ \\
\hline \multirow[t]{16}{*}{$689 \mathrm{~B}$} & $25-4,25-28$ & 6.13 & 93.87 & & 0.291 & 0.019 \\
\hline & $25-4,44-47$ & 4.88 & 95.12 & & 0.295 & 0.015 \\
\hline & $25-4,62-66$ & 4.94 & 95.06 & & 0.295 & 0.015 \\
\hline & $25-4,93-95$ & 5.20 & 94.80 & & 0.294 & 0.016 \\
\hline & $25-5,48-50$ & 9.73 & 90.27 & & 0.280 & 0.030 \\
\hline & $25-5,51-53$ & 8.37 & 91.63 & & 0.284 & 0.026 \\
\hline & $25-5,79-81$ & 9.52 & 90.48 & & 0.281 & 0.029 \\
\hline & $25-5,91-94$ & 6.79 & 93.21 & & 0.596 & 0.050 \\
\hline & $25-5,94-96$ & 6.43 & 93.57 & & 0.599 & 0.047 \\
\hline & $25-5,111-113$ & 5.70 & 94.30 & & 0.603 & 0.042 \\
\hline & $25-5,130-132$ & 4.56 & 95.44 & & 0.611 & 0.033 \\
\hline & $25-6,20-23$ & 2.44 & 97.56 & & 0.624 & 0.018 \\
\hline & $25-6,42-46$ & 5.18 & 94.82 & & 0.606 & 0.038 \\
\hline & $25-6,60-64$ & 20.57 & 79.43 & & 0.508 & 0.150 \\
\hline & $25-6,98-100$ & 2.06 & 97.94 & & 0.627 & 0.015 \\
\hline & $25, \mathrm{CC}$ & 4.82 & 95.18 & & 0.609 & 0.035 \\
\hline \multirow[t]{38}{*}{$690 \mathrm{C}$} & $14-1,81$ & & & 86.97 & 1.220 & 0.180 \\
\hline & $14-1,135$ & & & 55.39 & 0.780 & 0.630 \\
\hline & $14-2,20$ & & & 88.21 & 1.240 & 0.170 \\
\hline & $14-2,81$ & & & 77.22 & 1.090 & 0.320 \\
\hline & $14-2,135$ & & & 100.00 & 1.410 & 0.240 \\
\hline & $14-3,20$ & & & 83.05 & 1.170 & 0.200 \\
\hline & $14-3,81$ & & & 85.88 & 1.210 & 0.220 \\
\hline & $14-3,135$ & & & 84.63 & 1.190 & 0.170 \\
\hline & $14-4,115$ & & & 88.17 & 1.240 & 0.150 \\
\hline & $15-1,23$ & & & 89.13 & 1.250 & 0.180 \\
\hline & $15-1,132$ & & & 87.55 & 1.230 & 0.180 \\
\hline & $15-2,21-25$ & 12.44 & 87.56 & & 1.230 & 0.180 \\
\hline & $15-2,31$ & & & 87.05 & 1.230 & 0.200 \\
\hline & $15-2,46-50$ & 14.23 & 85.77 & & 1.210 & 0.200 \\
\hline & $15-2,94-96$ & 13.98 & 86.02 & & 1.210 & 0.200 \\
\hline & $15-2,132-136$ & 11.74 & 88.26 & & 1.240 & 0.170 \\
\hline & $15-2,135$ & & & 86.80 & 1.220 & 0.190 \\
\hline & $15-3,25-29$ & 12.03 & 87.97 & & 1.240 & 0.170 \\
\hline & $15-3,27$ & & & 85.22 & 1.200 & 0.210 \\
\hline & $15-3,41-46$ & 14.91 & 85.09 & & 1.200 & 0.210 \\
\hline & $15-3,95-97$ & 27.82 & 72.18 & & 1.020 & 0.390 \\
\hline & $15-3,132-136$ & 40.96 & 59.04 & & 0.830 & 0.580 \\
\hline & $15-3,136$ & & & 62.56 & 0.880 & 0.530 \\
\hline & $15-4,14$ & & & 48.40 & 0.130 & 0.140 \\
\hline & $15-4,28-30$ & 56.04 & 43.96 & & 0.120 & 0.150 \\
\hline & $15-4,45-47$ & 39.19 & 60.81 & & 1.220 & 0.790 \\
\hline & $15-4,84-86$ & 18.06 & 81.94 & & 1.650 & 0.360 \\
\hline & $15-4,104$ & & & 89.30 & 1.800 & 0.220 \\
\hline & $15-4,106-108$ & 10.22 & 89.78 & & 1.810 & 0.210 \\
\hline & $15-4,146-148$ & 18.32 & 81.68 & & 1.640 & 0.370 \\
\hline & $15-5,17$ & & & 80.97 & 1.630 & 0.380 \\
\hline & $15-5,25-28$ & 14.09 & 85.91 & & 1.730 & 0.280 \\
\hline & $15-5,76-78$ & 11.48 & 88.52 & & 1.780 & 0.230 \\
\hline & $15-5,106$ & & & 90.63 & 1.820 & 0.190 \\
\hline & $15-5,110-113$ & 10.46 & 89.54 & & 1.800 & 0.210 \\
\hline & $15-6,26$ & & & 77.97 & 1.570 & 0.440 \\
\hline & $15-6,124$ & & & 83.80 & 1.210 & 0.240 \\
\hline & $15-7,14$ & & & 85.47 & 1.230 & 0.210 \\
\hline
\end{tabular}

a hiatus at the top of Core 113-689B-25X. To estimate ages in this interval we assumed a sedimentation rate of $3.4 \mathrm{~m} / \mathrm{m} . \mathrm{y}$, similar to that of the preceding interval.

\section{ISOTOPIC DISEQUILIBRIUM AND $\delta^{18} \mathrm{O}$ CORRECTION FACTORS}

\section{Benthic Foraminifers}

Benthic foraminiferal assemblages in Holes 689B and 690C underwent various changes during the Late Cretaceous to the early Paleocene, indicating environmental variation at intermediate water depths (Thomas, this volume). Nonetheless, it was possible to pick and measure the same benthic foraminifer taxa over the $\mathrm{K} / \mathrm{P}$ boundary interval. The isotopic values for each taxa, including replicate analyses, are provided in Table 1.
Nuttallides and Gavelinella provide the most continuous benthic foraminifer record (Figs. 1 and 2). Osangularia is present in the interval spanning the $\mathrm{K} / \mathrm{P}$ boundary but occurs discontinuously above the lower part of Zone AP1a. Cibicidoides is present in several horizons below the $\mathrm{K} / \mathrm{P}$ boundary in Holes 689B and $690 \mathrm{C}$, does not occur within the boundary interval itself, and is present rarely in the lower Paleocene of both sites.

Distinct ${ }^{18} \mathrm{O}$ isotopic offsets exist between taxa in the sites (Figs. 1 and 2). In Hole 689B, Osangularia exhibits consistently higher values $(\sim 0.5 \%)$ than Nuttallides (Fig. 2). Osangularia, although not present continuously in the sequence, is on average $0.28 \%$ higher than Gavelinella. The discontinuous record of Cibicidoides makes it difficult to ascertain ${ }^{18} \mathrm{O}$ offsets from other taxa. The few measurements on Cibicidoides indicate no discernable offset from Gavelinella $(-0.04 \%)$ and Nuttallides $(0.01 \% 0)$. 


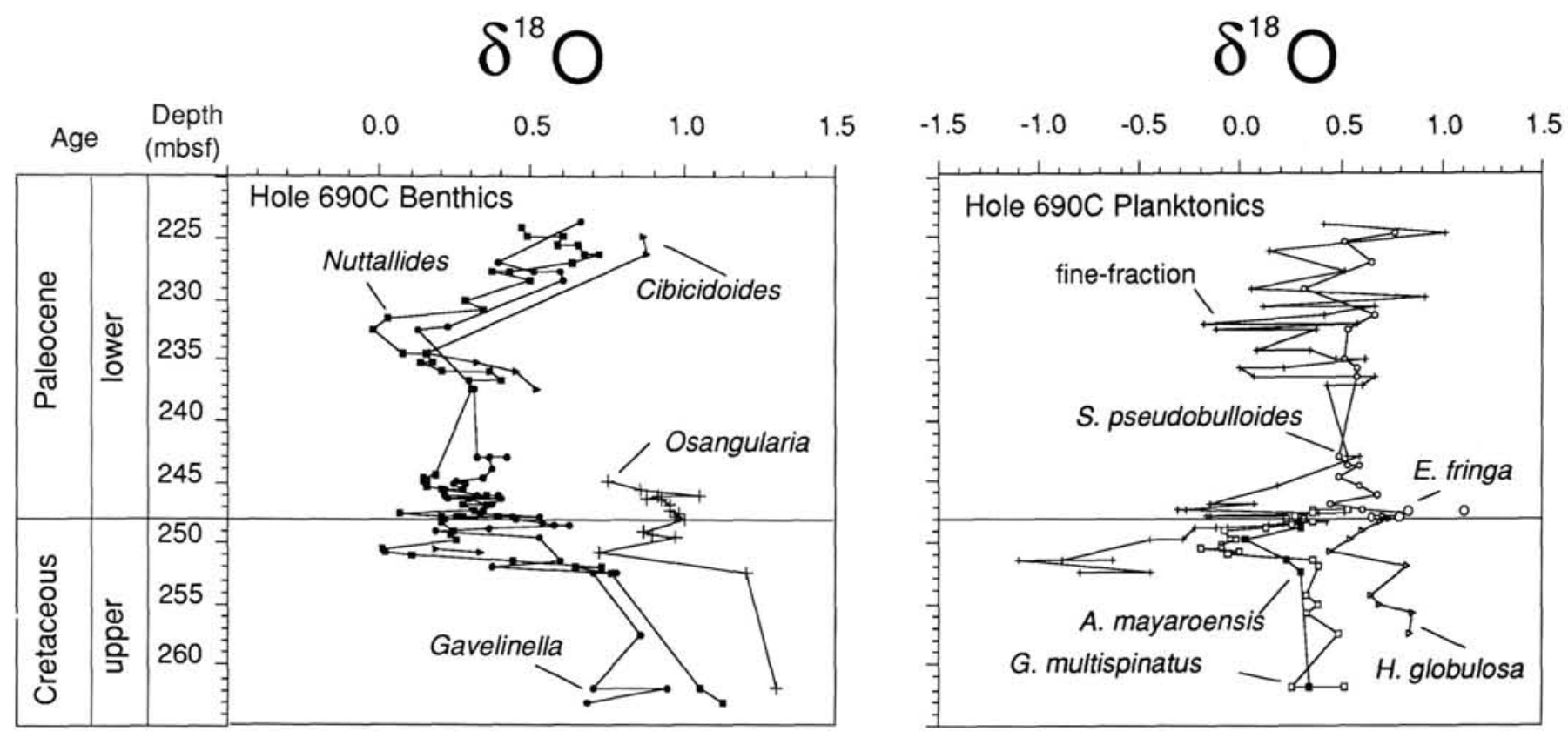

Figure 1. Benthic and planktonic foraminiferal $\delta^{18} \mathrm{O}$ plotted vs. depth in Hole $690 \mathrm{C}$. The isotopic values are actual measured values relative to PDB and have not been adjusted to account for potential disequilibrium offsets. Planktonic genera abbreviated in the figure are Abathomphalus (A.); Globigerinellinoides (G.): Heterohelix (H.); Eoglobigerina (E.); Subbotina (S.). Fine-fraction is primarily calcareous nannofossils.

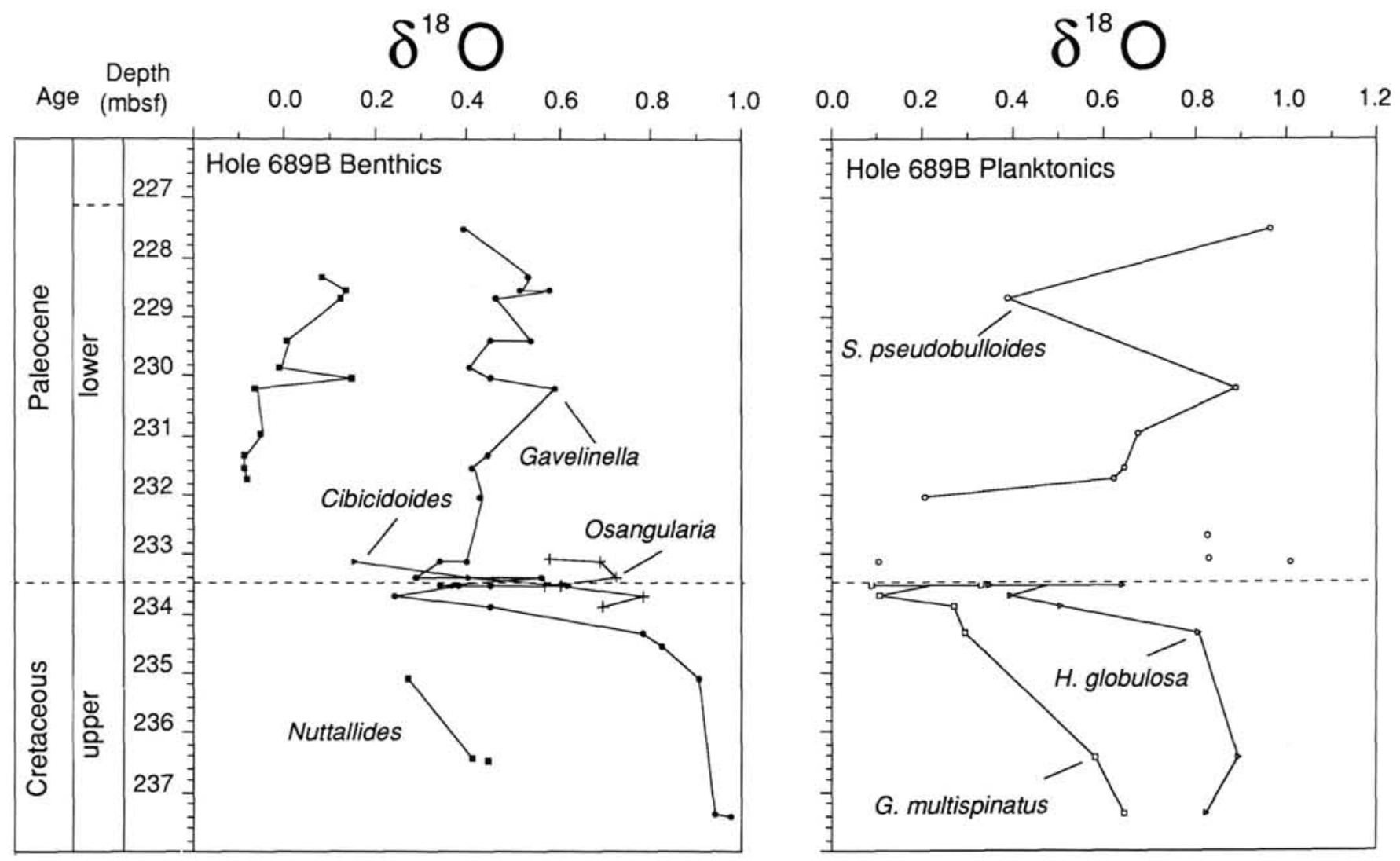

Figure 2. Benthic and planktonic foraminiferal $\delta^{18} \mathrm{O}$ plotted vs. depth in Hole 689B. The isotopic values are actual relative to PDB and have not been adjusted to account for potential disequilibrium offsets. 
In Hole 690C, Nuttallides and Gavelinella have essentially the same $\delta^{18} \mathrm{O}$ isotopic signature (within analytical precision). Consequently, the offset between these and other taxa is also similar (Table 1). The average offset between Cibicidoides and Nuttallides in Hole $690 \mathrm{C}$ is $0.17 \% 0$. This offset is similar to that observed in younger Paleogene horizons (Kennett and Stott, this volume) and is also consistent with reported offsets in other deep-sea sequences (Miller et al., 1987b). Osangularia consistently exhibits the highest $\delta^{18} \mathrm{O}$ values of any taxa analyzed. The offset between Osangularia and Nuttallides is $0.66 \%$ and is $0.59 \%$ between Osangularia and Gavelinella.

The $\delta^{18} \mathrm{O}$ offsets between taxa indicate that one or more of the taxa did not secrete their tests in isotopic equilibrium with respect to ambient seawater. Different isotopic offsets are generally attributed to metabolic factors termed "vital effects." The constancy of the offset between taxa within each site seems to support the idea that metabolic processes controlled disequilibrium in these benthic foraminifers. However, there are large differences in the inter-taxa offsets between Holes 689B and 690C. It has been suggested that different offsets in different locations may have resulted from varying environmental factors such as productivity in the overlying surface waters (Vincent et al., 1981). Sites 689 and 690 are too close to each another $(\sim 60 \mathrm{~km})$, however, to expect that there was any significant difference in surface-water productivity. It is possible that the difference in intertaxa offsets between the sites reflects diagenetic alteration of the benthic isotope record which we have not observed. Diagenetic alteration tends to reduce inter-taxa differences (Killingley, 1983). This may explain why the inter-taxa offsets are lower in Hole 689B than in Hole 690C. Paleotemperatures have not been determined from the Hole 689B benthic isotope data because of potential diagenetic problems. Further trace element work is needed in order to better evaluate the preservational quality of these samples.

We have applied a $\delta^{18} \mathrm{O}$ correction to Cibicidoides values from Hole $690 \mathrm{C}$ of $0.64 \%$, consistent with that used in other intervals of the Cenozoic by Kennett and Stott (this volume). Other taxa in turn have been corrected to Cibicidoides based on the offsets discussed above. No correction was applied to $\delta^{13} \mathrm{C}$ values because all the taxa analyzed display essentially the same isotopic signature. Modern Cibicidoides has been shown to secrete its test close to isotopic equilibrium (Woodruff et al., 1981). We have assumed that this was the case for Late Cretaceous and early Paleogene forms.

\section{Planktonic Foraminifers and Calcareous Nannofossils}

\section{Oxygen Isotopes}

Although none of the planktonic foraminiferal taxa studied are extant, the bulk of evidence from studies of modern planktonic foraminifers suggests that most species secrete their tests close to oxygen isotopic equilibrium (for review, see Mix, 1987). However, planktonic foraminifers migrate within the water column and their isotopic composition can thus vary. In order to minimize this potential variability, we analyzed only specimens of similar size. Further, the final chamber of some G. multispinatus specimens are bulla-like coverings extending over the apertural regions and may represent a gametogenic stage. Such specimens were not included in the isotope samples. We have assumed that oxygen isotopic differences between planktonic foraminiferal taxa reflect differences in the water temperature in which they lived. This can result from depth or seasonal preferences. On the other hand, modern calcareous nannoplankton grown in culture have been shown to secrete calcite as much as $1 \%$ enriched to $2.5 \%$ depleted in ${ }^{18} \mathrm{O}$ relative to calcium carbonate precipitated under equilibrium conditions (Dudley et al., 1986). This disequilibrium fractionation appears to be species- specific. The calcareous nannofossil samples analyzed from Holes $689 \mathrm{~B}$ and $690 \mathrm{C}$ contain varying proportions of different taxa, each with potentially very different isotopic values. This is a reflection of bioturbation and the species original relative abundance. The potential exists therefore, for considerable isotopic variability over the $\mathrm{K} / \mathrm{P}$ boundary in response to the significant changes in species composition that occurred at that time and any associated disequilibrium effects that may have been caused by environmental factors (see Stott et al., this volume).

Isotopic paleotemperatures were calculated using the relationship between oxygen isotopic fractionation and temperature as described by O'Neil et al. (1969) and following the considerations discussed by Shackleton (1974). For the reasons cited above, greater emphasis is given to the isotopic results from planktonic foraminifer samples in the interpretation of isotopic temperatures.

\section{Carbon Isotopes}

The carbon isotopic record across the $\mathrm{K} / \mathrm{P}$ boundary has not previously been studied using continuous samples of single benthic and planktonic foraminifer species. Previous studies have relied on either bulk carbonate (representing a mixture of benthic and planktonic foraminifers and calcareous nannofossils), fine fraction carbonate (primarily calcareous nannofossils and juvenile planktonic foraminifers), mixed benthic assemblages or mixed planktonic foraminifer assemblages or discontinuous measurements of single species within their stratigraphic ranges. Planktonic foraminifers, calcareous nannofossils, and benthic foraminifers all exhibit different isotopic compositions reflecting different habitats within the water column and possibly varying degrees of isotopic disequilibrium (Figs. 3 and 4). Modern trochospiral benthic foraminifers seem to be the least susceptible to $\delta^{13} \mathrm{C}$ disequilibrium (Graham et al., 1981; Vincent et al., 1981; Woodruff et al., 1981). Planktonic taxa on the other hand vary considerably in disequilibrium effects (Shackleton et al., 1973; Williams et al., 1977; Shackleton and Vincent, 1978; Curry and Matthews, 1981; Erez and Honjo, 1981; Kahn and Williams, 1981; Fairbanks et al., 1982; Dunbar, 1983; Dudley et al., 1986). In general, $\delta^{13} \mathrm{C}$ disequilibrium effects are poorly understood and are usually attributed to metabolic processes. A few studies have shown that photosymbiont-bearing benthic and planktonic foraminifers can display marked departures from carbon isotopic equilibrium (Williams et al., 1981; Zimmerman et al., 1983; Spero and DeNiro, 1987). Varying light intensity seems to cause a considerable $\delta^{13} \mathrm{C}$ fractionation effect in the shells of photosymbiont-bearing planktonic foraminifers (Spero and Williams, 1988). It is not possible to demonstrate that $E$. fring $a$ and $S$. pseudobulloides did not contain photosymbionts. However, these planktonic species do not display evidence of spines or spine bases that are usually associated with symbiotic behavior in modern forms (Bé, 1982).

\section{ISOTOPIC RESULTS}

Isotopic results from the Late Cretaceous to early Paleocene are described based upon several time intervals during which there appear to exist distinct patterns in the isotopic records.

\section{Planktonic and Benthic $\delta^{18} \mathrm{O}$ and Vertical Temperature Gradients}

\section{0-66.7 Ma.}

Changes in the water column vertical oxygen isotopic temperature gradient before the $\mathrm{K} / \mathrm{P}$ transition have been evaluated by comparison of the $\delta^{18} \mathrm{O}$ records for several planktonic foraminifer species, the calcareous nannofossil samples, and benthic foraminifers (Figs. 5 and 6). During the latter part of the A. mayaroensis Zone between 68 and $66.7 \mathrm{Ma}$, distinct $\delta^{18} \mathrm{O}$ 

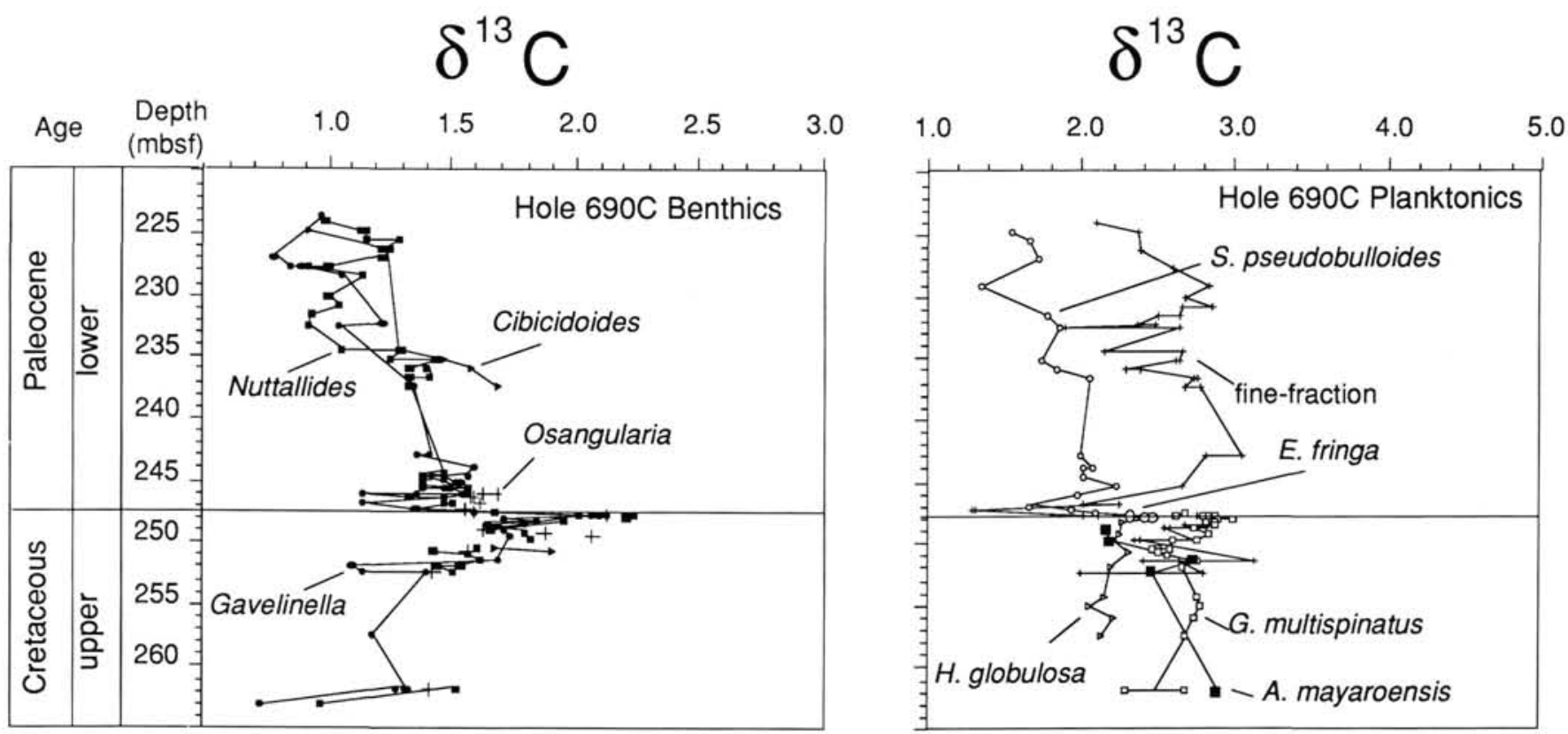

Figure 3. Benthic and planktonic foraminiferal $\delta^{13} \mathrm{C}$ plotted vs. depth in Hole $690 \mathrm{C}$. The isotopic values are actual measured values relative to PDB and have not been adjusted to account for potential disequilibrium offsets.

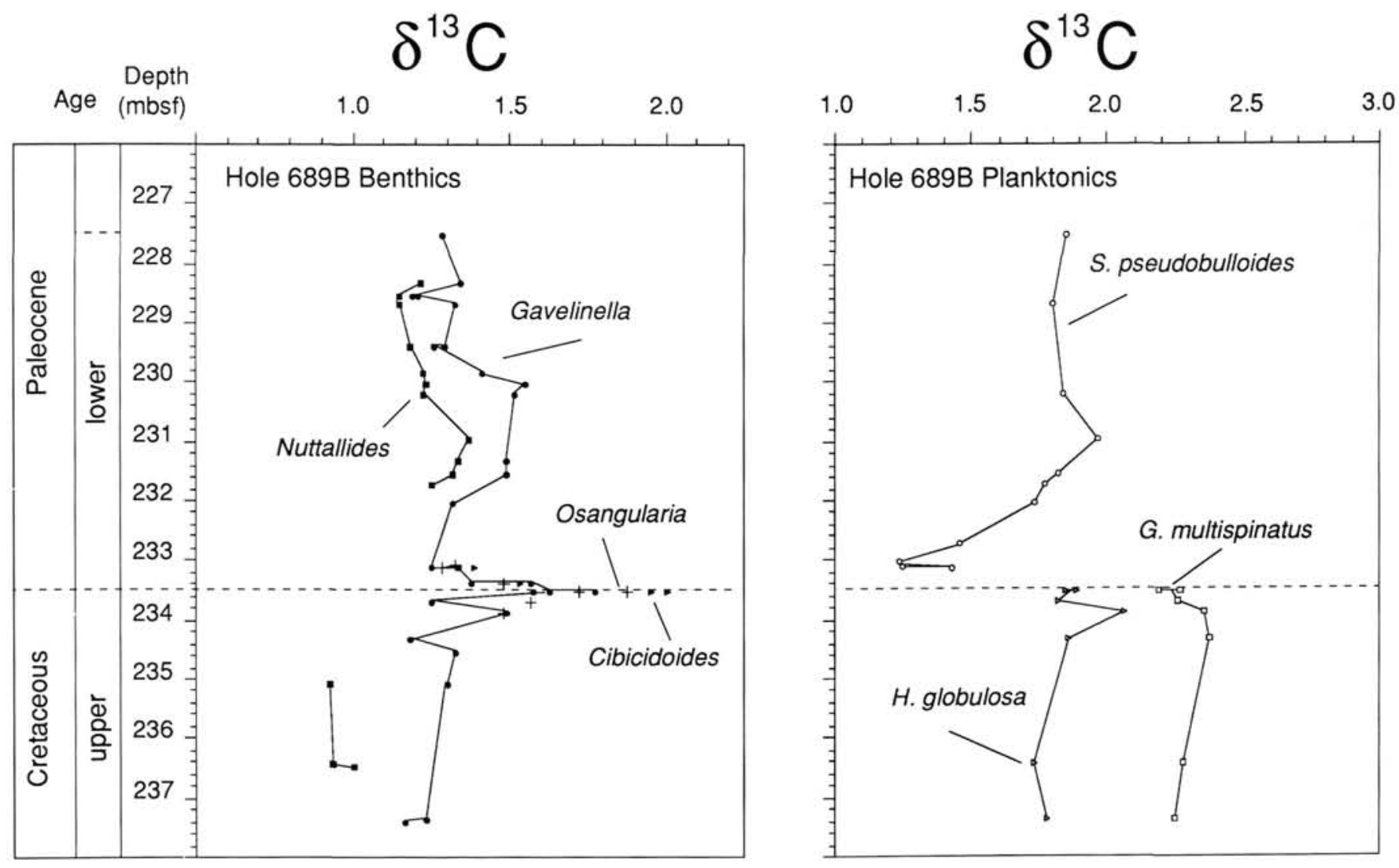

Figure 4. Benthic and planktonic foraminiferal $\delta^{13} \mathrm{C}$ plotted vs. depth in Hole 689B. The isotopic values are measured values relative to PDB and have not been adjusted to account for potential disequilibrium offsets. 


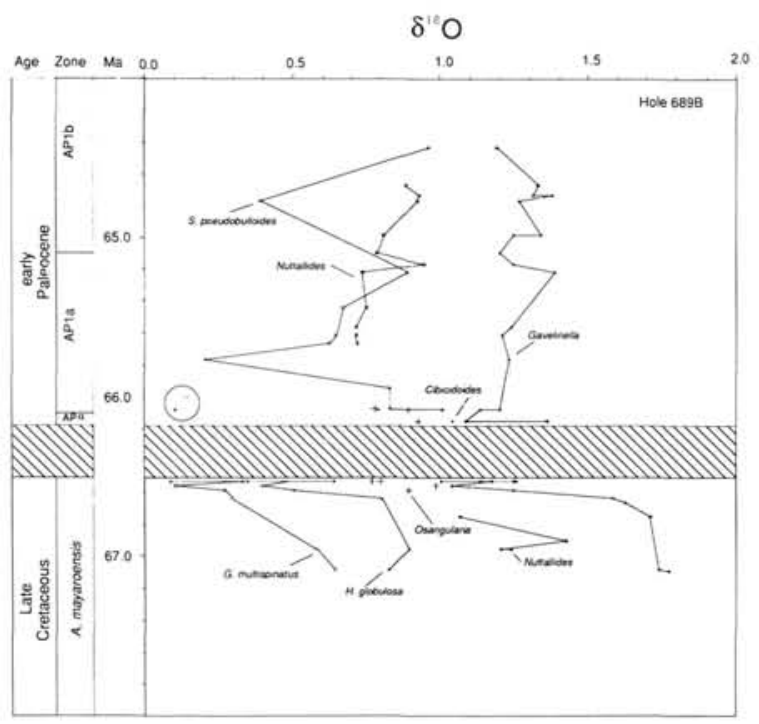

Figure 5. Planktonic and benthic foraminiferal $\delta^{18} \mathrm{O}$ relative to PDB vs. age in Hole 689B. Benthic $\delta^{18} \mathrm{O}$ values reflect adjustments to account for disequilibrium effects. Planktonic foraminiferal values encircled are almost certainly incorrect and were analyzed using very small samples. Planktonic foraminifer zonation is after Stott and Kennett (this volume, chapter 34). Hatched zone represents disconformity. Ages are derived by magnetobiostratigraphic correlations to the standard time scale of Berggren et al. (1985).

\section{$\delta^{18} \mathrm{O}$}

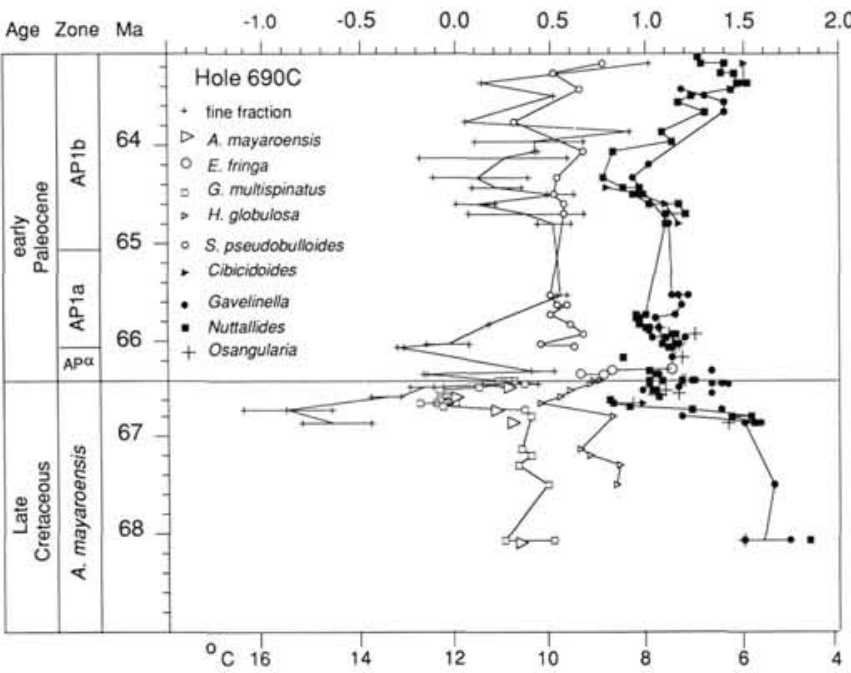

Figure 6. Planktonic and benthic foraminiferal and calcareous nannofossil $\delta^{18} \mathrm{O}$ relative to PDB vs. age in Hole $690 \mathrm{C}$. Benthic $\delta^{18} \mathrm{O}$ values reflect adjustments to account for disequilibrium effects. Paleotemperature scale is after O'Neil et al. (1969). Magnetostratigraphy is that of Hamilton (this volume). Planktonic foraminifer zonation is after Stott and Kennett (this volume, chapter 34). Ages are derived by magnetobiostratigraphic correlations to the standard time scale of Berggren et al. (1985). contrasts existed between planktonic foraminifer species and calcareous nannofossil carbonate (Figs. 5 and 6). A. mayaroensis and G. multispinatus exhibit $\delta^{18} \mathrm{O}$ values that average $0.3 \%_{0}-0.5 \%$ ( $\sim 10^{\circ} \mathrm{C}$ assuming isotopic equilibrium). $\mathrm{H}$. globulosa values are the highest of any planktonic taxa analyzed from this interval $\left(\sim 0.8 \% \%_{0}-0.7 \%\right.$ ) reflecting temperatures of $\sim 8^{\circ} \mathrm{C}$. Benthic foraminiferal $\delta^{18} \mathrm{O}$ values are $\sim 1.7 \% 0-1.5 \%$ (inferred deep-water temperatures of $\sim 4^{\circ}-5^{\circ} \mathrm{C}$ ).

\section{7-66.6 Ma.}

The relative stability of the isotopic values that characterized the interval between 68.0 and $66.7 \mathrm{Ma}$ were replaced during the subsequent $100 \mathrm{k} . \mathrm{y}$. by a sharp decrease in planktonic and benthic $\delta^{18} \mathrm{O}$ values. Planktonic values decreased during this interval by $0.5 \% 0-0.7 \% 0$ (Figs. 5 and 6 ). Isotopic temperatures of surface waters, based on the values of $G$. multispinatus, increased from $10^{\circ} \mathrm{C}$ at $66.7 \mathrm{Ma}$ to $\sim 12^{\circ} \mathrm{C}$ by $66.6 \mathrm{Ma}$ (Figs. 5 and 6). We lack isotopic values from the fine-fraction below $66.8 \mathrm{Ma}$, hence, it is difficult to evaluate the magnitude of the negative isotopic excursion recorded by this fossil group. However, there was a decrease from $-0.7 \%_{0}\left(\sim 14^{\circ} \mathrm{C}\right)$ to $\sim-1.0 \%_{0}\left(15^{\circ} \mathrm{C}\right)$ between $\sim 66.72$ and $\sim 66.72 \mathrm{Ma}$ (Fig. 7). The subsequent sample above this is dated at $\sim 66.5 \mathrm{Ma}$.

Benthic values also decreased within this interval by an amount similar to that observed in the planktonic foraminifer records. Between 66.7 and 66.6 Ma Nuttallides values decreased in Hole $690 \mathrm{C}$ from $\sim 1.3 \%$ to $0.7 \% 0$. This implies a warming of intermediate waters from $\sim 7^{\circ} \mathrm{C}$ at $66.7 \mathrm{Ma}$ to $\sim 9^{\circ} \mathrm{C}$ at $66.6 \mathrm{Ma}$. Taken together, the planktonic and benthic results indicate that this warming event occurred uniformly throughout the water column. Nuttallides values reflect a slight warming prior to $66.7 \mathrm{Ma}$ (Fig. 7) but our sample resolution is low. Additional samples through this interval are needed in order to determine if the benthic values began to warm slightly before the planktonic values.

\section{6-66.4 Ma.}

The maximum temperatures recorded at $66.6 \mathrm{Ma}$ lasted only briefly and were replaced by a trend toward higher isotopic values beginning at $\sim 66.6 \mathrm{Ma}$ (Figs. 6 . 7). Calcareous nannofossils, $G$. multispinatus and $A$. mayaroensis increased from between $\sim-0.5 \%_{0}$ and $0 \%_{0}$ to $0.5 \%_{0}$ during the $200 \mathrm{k}$.y. preceding the $\mathrm{K} / \mathrm{P}$ boundary. The increase in $\delta^{18} \mathrm{O}$ of $\sim 1 \%$ reflects a cooling of surface waters from $\sim 14^{\circ} \mathrm{C}$ to about $10^{\circ} \mathrm{C}$. $\mathrm{H}$. globulosa and benthic foraminifers exhibit parallel shifts but the magnitude of change is smaller, particularly in the benthic record $(\sim 0.3 \%)$. The isotopic offsets between planktonic taxa appear to converge between 66.7 and $66.4 \mathrm{Ma}$ (Fig. 7). This convergence is a result of smaller changes in $H$. globulosa $\delta^{18} \mathrm{O}$ values, reflecting an isotopic temperature change of only $1^{\circ}-2^{\circ} \mathrm{C}$ compared to the $3^{\circ}-5^{\circ} \mathrm{C}$ change in the other two planktonic taxa. The shift in benthic $\delta^{18} \mathrm{O}$ values is even smaller than that of $H$. globulosa and indicates an isotopic temperature decrease of no more than $1.5^{\circ} \mathrm{C}$.

\section{4-63.0 $\mathrm{Ma}$.}

The positive $\delta^{18} \mathrm{O}$ shift that began at $66.6 \mathrm{Ma}$ continued briefly (for $\sim 0.1 \mathrm{Ma}$ ) into the earliest Paleogene $(66.3 \mathrm{Ma})$, based on relatively high $\delta^{18} \mathrm{O}$ values for $E$. fring $a$ and calcareous nannofossil carbonate (Fig. 7). Following this, between 66.3 and 66.1 $\mathrm{Ma}$, planktonic foraminiferal $\delta^{18} \mathrm{O}$ values reflect a slight warming trend of $\sim 2{ }^{\circ} \mathrm{C}$ (Fig. 7). In the latter part of the APla Zone we have fewer isotopic measurements. However, between 66.1 and $65.0 \mathrm{Ma}$, the planktonic foraminifer $\delta^{18} \mathrm{O}$ values changed little, which suggests that climatic conditions had stabilized during this interval. There was a small decrease in benthic foraminifer and fine-fraction isotopic values between 65.0 and $64.5 \mathrm{Ma}$. In benthic values this is most evident in Gavelinella, Nuttalli- 


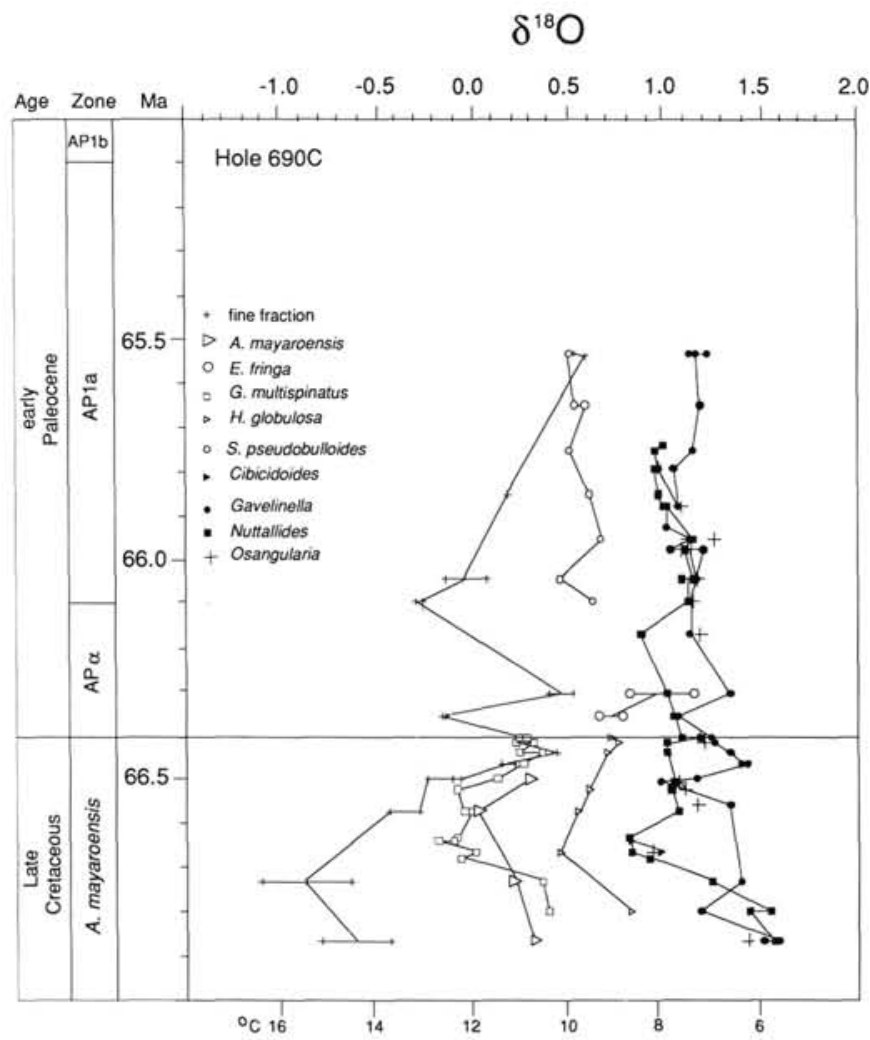

Figure 7. Detailed view of planktonic and benthic $\delta^{18} \mathrm{O}$ values relative to PDB in Hole $690 \mathrm{C}$ (Fig. 6) over the K/P boundary showing a reduction in the differences in $\delta^{18} \mathrm{O}$ values between various planktonic species and an inferred reduction in surface-to-deep water isotopic temperature gradient.

des, and a few Cibicidoides samples from $\sim 1.2 \%_{0}$ to $0.8 \%$. In the planktonic foraminifer record there appears to have been less change than that recorded by the benthic foraminifers. The reproducibility of the fine-fraction samples is poor in this interval, making it difficult to infer accurate trends in that data set. The latter part of the APla Zone is marked by a trend toward higher benthic $\delta^{18} \mathrm{O}$ values. Planktonic foraminifer values did not record this increase in $\delta^{18} \mathrm{O}$.

The record outlined above indicates that although there was a slight warming $\left(\sim 1.5^{\circ} \mathrm{C}\right)$ shortly after $66.3 \mathrm{Ma}$, the cooling trend that began $200 \mathrm{k} . \mathrm{y}$. before the K/P boundary appears to have produced a permanent reduction of Paleocene surface-water temperatures of $\sim 1^{\circ}-2^{\circ} \mathrm{C}$. Benthic $\delta^{18} \mathrm{O}$ values did not change significantly across the $\mathrm{K} / \mathrm{P}$ boundary, nor during the early $\mathrm{Pa}$ leogene. Deep waters had already warmed to their post $\mathrm{K} / \mathrm{P}$ boundary values before the surface-water cooling event occurred (Fig. 6). Consequently, the surface (based upon G. multispinatus values) to deep water (based upon benthic values) temperature gradient was reduced slightly across the $\mathrm{K} / \mathrm{P}$ boundary (Figs. 6 and 7).

The isotopic results from Hole 689B (Fig. 5) generally agree with the patterns of change observed in Hole $690 \mathrm{C}$. The benthic isotope values reflect relatively little change in the interval during and following the $\mathrm{K} / \mathrm{P}$ boundary. Nuttallides values are considerably lower than those of Gavelinella and exhibit values similar to those of the planktonic foraminifers. Because $E$. fringa and $S$. pseudobulloides values from Hole 689B are similar to those observed in Hole $690 \mathrm{C}$, the isotopic values of Nuttallides, or the correction factors applied to them, may be in error. Alter- natively, there may be a diagenetic imprint which we did not identify visually.

\section{Planktonic and Benthic $\delta^{13} \mathrm{C}$ Values and the Vertical $\Delta \delta^{13} \mathbf{C}$ Gradient}

\section{0-66.7 Ma.}

Distinct differences exist between the carbon isotopic values of the various planktonic groups (Figs. 8 and 9). Carbon isotopic values of the planktonic foraminifer $G$. multispinatus were on average $2.7 \%$ within this interval. Values for $H$. globulosa during this interval average $\sim 2.1 \%$. The benthic forms, Nuttallides, Gavelinella, Osangularia, and Cibicidoides all exhibit similar $\delta^{13} \mathrm{C}$ values of between $\sim 1.1 \% 0$ and $1.5 \% 0$ in Hole $690 \mathrm{C}$, although the number of isotopic measurements is relatively small compared to the planktonic record. In Hole 689B, Nuttallides exhibits lower values than that of Gavelinella, but again, the number of measurements is relatively small within this interval. The vertical $\Delta \delta^{13} \mathrm{C}$ gradient during this interval, based on the offset between $G$. multispinatus and Gavelinella averages $\sim 1.2 \% 0$ (Fig. 8).

Because there may have been as much as $1000 \mathrm{~m}$ water depth separating the two Maud Rise sites during the Late Cretaceous, it is possible that a $\delta^{13} \mathrm{C}$ gradient existed between them. However, this probable gradient should have been minor compared to the much larger gradient between surface (planktonic $\delta^{13} \mathrm{C}$ ) and deep waters (benthic $\delta^{13} \mathrm{C}$ ). Based upon the limited data we have for this interval, we are unable to discern any $\delta^{13} \mathrm{C}$ gradient between the two Maud Rise sites. It is apparent however, that the surface-to-deep water $\delta^{13} \mathrm{C}$ gradient was well developed during this interval at both locations.

\section{7-66.4 Ma.}

Beginning at $\sim 66.7 \mathrm{Ma}$, and in conjunction with the positive $\delta^{18} \mathrm{O}$ shift described earlier (Fig. 7), benthic and planktonic

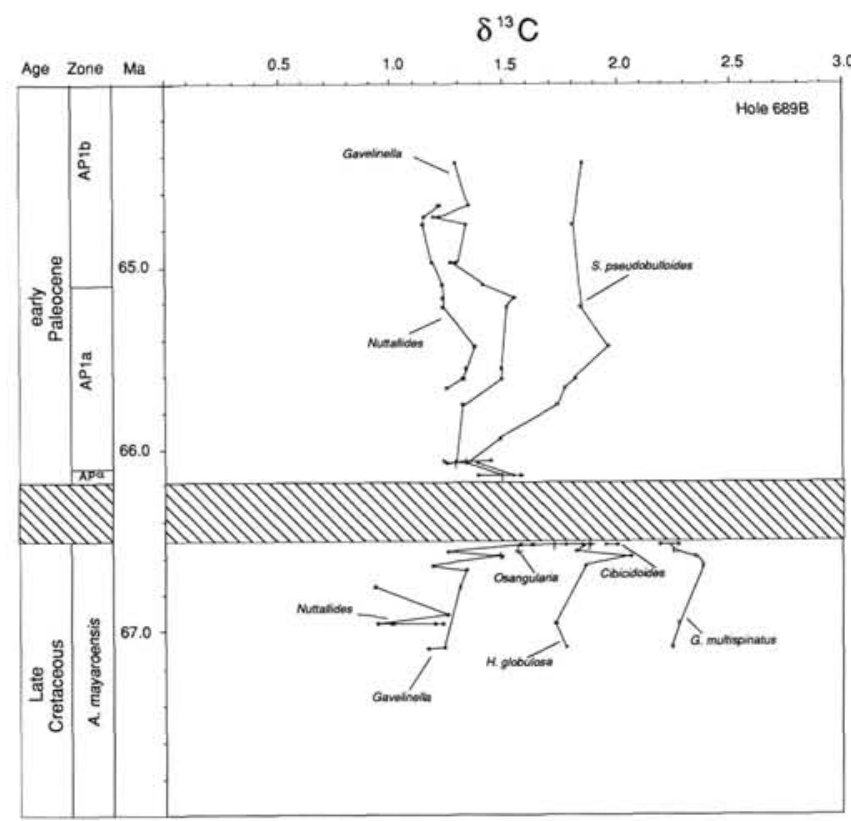

Figure 8. Planktonic and benthic $\delta^{13} \mathrm{C}$ relative to $\mathrm{PDB}$ vs. age in Hole 689B. A brief hiatus spans the K/P boundary. A notable decrease in planktonic $\delta^{13} \mathrm{C}$ occurs across the hiatus and the K/P boundary. Planktonic foraminifer zonation is after Stott and Kennett (this volume, chapter 34). Ages are after Berggren et al. (1985). 


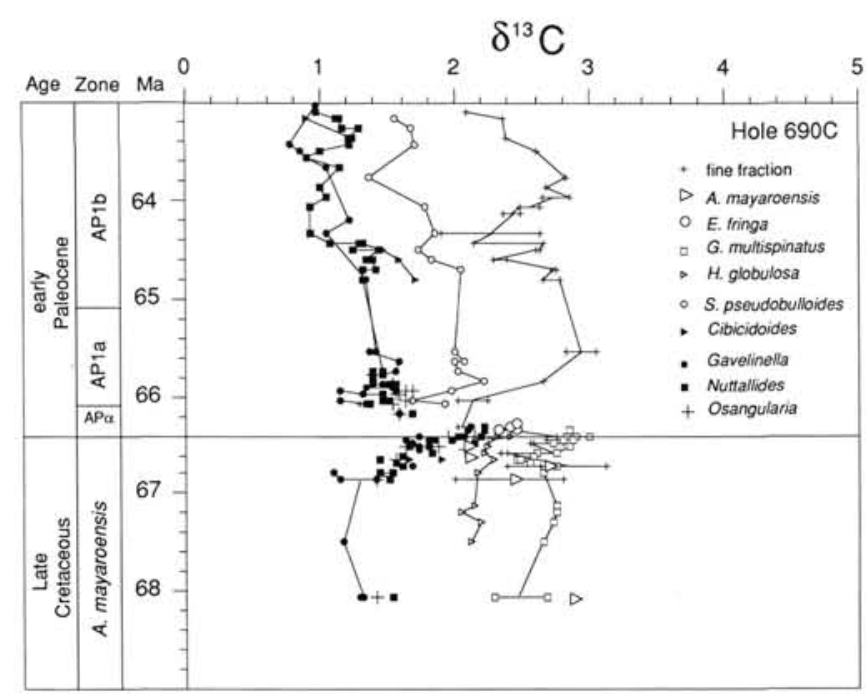

Figure 9. Planktonic and benthic $\delta^{13} \mathrm{C}$ relative to $\mathrm{PDB}$ vs. age in Hole $690 \mathrm{C}$. Note the marked $\delta^{13} \mathrm{C}$ increase prior to the $\mathrm{K} / \mathrm{P}$ boundary, a positive peak in close association with the boundary, followed by a distinct decrease in the earliest Paleogene. Lines connecting isotopic values were eliminated in some intervals to make visualization of the data easier. The surface-to-deep water $\delta^{13} \mathrm{C}$ gradient was significantly reduced in the earliest Paleogene, although a gradient $\left(\Delta \delta^{13} \mathrm{C}=\sim 0.4 \%\right.$ ) remained. The gradient between planktonic and benthic $\delta^{13} \mathrm{C}$ was rapidly re-established soon after 66.1 Ma. Planktonic foraminifer zonation is after Stott and Kennett (this volume, chapter 34). Ages are after Berggren et al. (1985).

foraminifer $\delta^{13} \mathrm{C}$ values in Hole $690 \mathrm{C}$ began to increase rapidly (Fig. 10). $\delta^{13} \mathrm{C}$ values in G. multispinatus and calcareous nannofossils increased from $2.56 \%$ at $66.7 \mathrm{Ma}$ to between $2.8 \%$ and $3.0 \%$ at $\sim 66.4 \mathrm{Ma}$, at the $\mathrm{K} / \mathrm{P}$ boundary (Fig. 10). The benthic foraminifers Gavelinella and Nuttallides increased from $\sim 1.6 \%$ to $\sim 2.0 \%$ during this interval. $H$. globulosa values are intermediate between those of $G$. multispinatus and benthic foraminifers but exhibit the same $\delta^{13} \mathrm{C}$ shift. In Hole 689B the benthic foraminifer $\delta^{13} \mathrm{C}$ began to exhibit the same trend, but the record is truncated by a hiatus (Fig. 8).

\section{4-63.0 Ma.}

At the K/P boundary and for the succeeding $100 \mathrm{k} . \mathrm{y}$., benthic $\delta^{13} \mathrm{C}$ values remained high, averaging $2.1 \% 0-2.2 \%$ (Fig. 10). During the 100 k.y. following the $\mathrm{K} / \mathrm{P}$ boundary, $E$. fringa $\delta^{13} \mathrm{C}$ values were $\sim 2.5 \%$. These values are lower than the latest Cretaceous values of $G$. multispinatus. However, they are similar to those of $H$. globulosa during the Late Cretaceous. The few $H$. globulosa and $G$. multispinatus samples we analyzed from above the $\mathrm{K} / \mathrm{P}$ boundary (Table 1 ) had isotopic values similar to those of the Late Cretaceous and did not show any distinct reduction in isotopic composition. If these two species were Cretaceous survivors this would imply a relatively high $\Delta \delta^{13} \mathrm{C}$ gradient in the earliest Paleocene, not a reduced gradient as shown by differences between $E$. fring $a$ and benthic foraminifers. If, on the other hand, most of the specimens of $G$. multispinatus and $H$. globulosa analyzed in these early Paleocene samples were reworked from the Cretaceous, then nothing can be inferred from these measurements about the Paleocene $\Delta \delta^{13} \mathrm{C}$ gradient. Based upon the measured offset between $E$. fring $a$ and the benthic forms Gavelinella and Nuttallides $\left(0.3 \%_{0}-0.4 \%\right.$ ) the surface-todeep water $\delta^{13} \mathrm{C}$ gradient in the early Paleocene, was more similar to differences observed for the latest Cretaceous between benthic foraminifers and $H$. globulosa $(0.5 \% 0-0.7 \%)$.

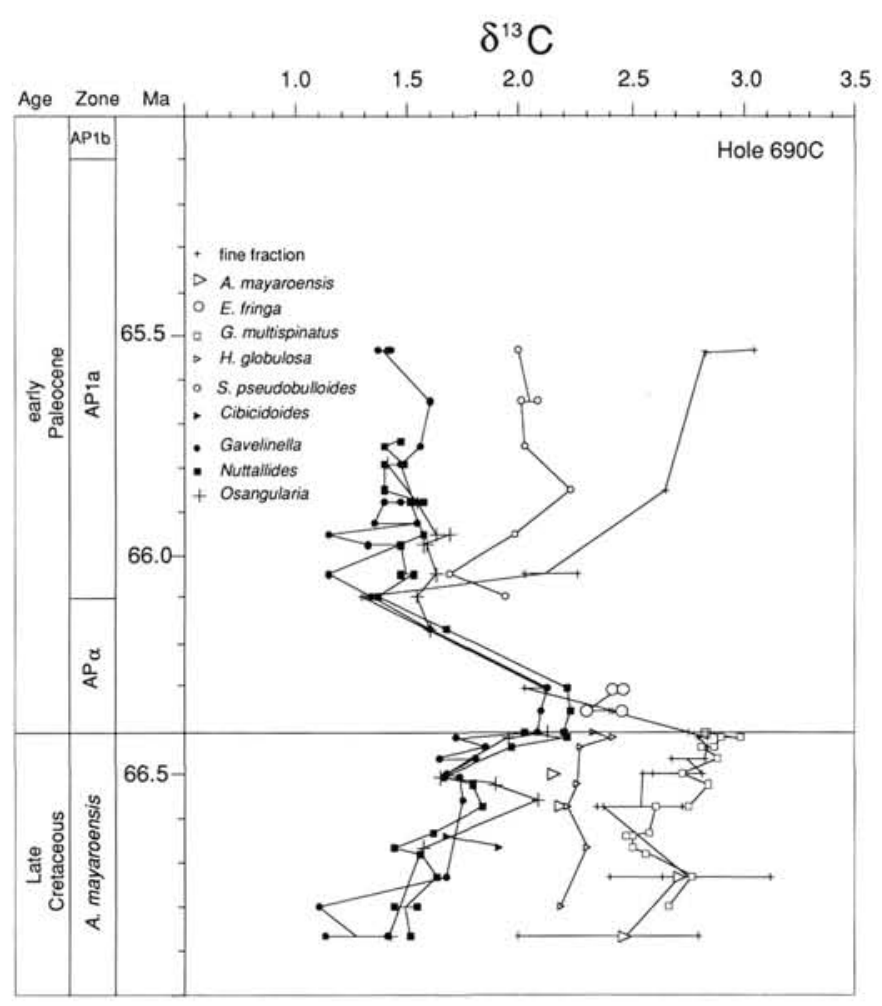

Figure 10. Details of planktonic and benthic $\delta^{13} \mathrm{C}$ relative to PDB vs. age in Hole $690 \mathrm{C}$ from Figure 9. There was no apparent reduction in the vertical $\delta^{13} \mathrm{C}$ gradient before the $\mathrm{K} / \mathrm{P}$ boundary. Benthic $\delta^{13} \mathrm{C}$ values remained high following the K/P boundary for $\sim 100 \mathrm{k} . \mathrm{y}$. before decreasing in a negative excursion to $66 \mathrm{Ma}$. Calcareous nannofossil $\delta^{13} \mathrm{C}$ values decreased anomalously across the $\mathrm{K} / \mathrm{P}$ boundary to values more negative than benthic foraminifers. Planktonic foraminiferal $\delta^{13} \mathrm{C}$ also show a marked decrease over the boundary but remained more positive than benthic foraminifers.

From 66.3 to $66.0 \mathrm{Ma}$ the isotopic record exhibits several distinct features. In addition to the reduced $\Delta \delta^{13} \mathrm{C}$ noted above, benthic and planktonic $\delta^{13} \mathrm{C}$ values became increasingly more negative between 66.3 and $66.0 \mathrm{Ma}$ (Fig. 10). Within this negative $\delta^{13} \mathrm{C}$ excursion, calcareous nannofossil values are lower than any other taxa, including benthic foraminifers. The $\delta^{13} \mathrm{C}$ values of calcareous nannofossils decreased from $2.4 \% 0$ at $66.36 \mathrm{Ma}$ to $1.3 \%$ at $66.1 \mathrm{Ma}$ (Fig. 10). Benthic foraminifers reflect a similar negative excursion but are $0.2 \% 0-0.4 \%$ higher than the finefraction carbonate. The $\delta^{13} \mathrm{C}$ values of $E$. fringa also declined during this interval but there is a gradual increase in the gradient between this planktonic foraminifer and the benthic taxa (Fig. 10). Planktonic foraminifer $\delta^{13} \mathrm{C}$ values were higher for the first 100 k.y. of the Paleocene than at any time during the subsequent 2.0 m.y. (Fig. 10).

Coincident with the base of the $S$. pseudobulloides Subzone (AP1a), in Hole 690C and the first appearance of several planktonic taxa (Stott and Kennett, this volume, chapter 34), there is a sharp increase in the $\delta^{13} \mathrm{C}$ of both planktonic foraminifers and calcareous nannofossils. The $\delta^{13} \mathrm{C}$ of calcareous nannofossils increased from $1.3 \%$ at 66.1 to $2.0 \%$ at $66.05 \mathrm{Ma}$ (Figs. 9 and 10). Planktonic foraminifer $\delta^{13} \mathrm{C}$ also began to increase rapidly at $66.1 \mathrm{Ma}$. By $65.7 \mathrm{Ma}$, the $\delta^{13} \mathrm{C}$ gradient between benthic foraminifers and the planktonic foraminifer $S$. pseudobulloides was $\sim 0.7 \%$. The $\Delta \delta^{13} \mathrm{C}$ between benthic foraminifers and calcareous nannofossils was even greater (Fig. 10). It appears, therefore, that the surface-to-deep water $\delta^{13} \mathrm{C}$ gradient was reestablished to 
pre-K/P boundary levels by $66.05 \mathrm{Ma}$. Between $\sim 66.0$ and 63.0 $\mathrm{Ma}$ benthic values decreased slightly, although values fluctuated considerably (Fig. 9). The planktonic foraminifer record reflects a similar trend toward slightly lower values.

\section{CALCIUM CARBONATE ACCUMULATION RATES}

Calcium carbonate (wt \%) and calcium carbonate accumulation rates (in $\mathrm{g} / \mathrm{cm}^{2} / \mathrm{k}$.y.) are plotted in Figures 11 and 12 . Both sites contain high carbonate content in the Late Cretaceous, averaging between $80 \%$ and $90 \%$ (Fig. 11). The sample preceding the $\mathrm{K} / \mathrm{P}$ boundary $(\sim 66.41 \mathrm{Ma})$ in Hole $690 \mathrm{C}$ shows the beginning of a trend toward lower carbonate percentages in the earliest Paleocene (Fig. 11). The lowest values are recorded within the earliest Paleocene at $\sim 66.3 \mathrm{Ma}(\sim 40 \%)$ and increased again to pre-K/P values by $66 \mathrm{Ma}$ (Fig. 11). We cannot determine whether the relatively low carbonate values just below the boundary in Hole $690 \mathrm{C}$ resulted from bioturbation, downward mixing of early Paleocene material, or whether carbonate percentages decreased prior to the boundary. In Hole 689B, the hiatus associated with the $\mathrm{K} / \mathrm{P}$ boundary precludes any inference about changes that may have occurred in the boundary interval; there is little difference in values above and below the hiatus.

Calcium carbonate accumulation rates in Hole 690C (Fig. 12) exhibit a trend toward higher values during the last few hundred thousand years of the Late Cretaceous, between $\sim 66.7$ and $\sim 66.45 \mathrm{Ma}$. During this interval values increased from $\sim 1.1 \mathrm{~g} / \mathrm{cm}^{2} / \mathrm{k}$.y. to between 1.5 and $1.8 \mathrm{~g} / \mathrm{cm}^{2} / \mathrm{k}$.y. Immediately below the $\mathrm{K} / \mathrm{P}$ boundary, beginning at $\sim 66.45 \mathrm{Ma}$, values decreased again to $\sim 1.2 \mathrm{~g} / \mathrm{cm}^{2} / \mathrm{k}$.y. and continued to decrease across the boundary to $\sim 0.1 \mathrm{~g} / \mathrm{cm}^{2} / \mathrm{k}$.y. Values remained low $\left(\sim 0.2 \mathrm{~g} / \mathrm{cm}^{2} / \mathrm{k} . \mathrm{y}\right.$.) within the AP $\alpha$ Zone. At the base of the succeeding AP1a Zone the values began to increase again to $\sim 0.8$

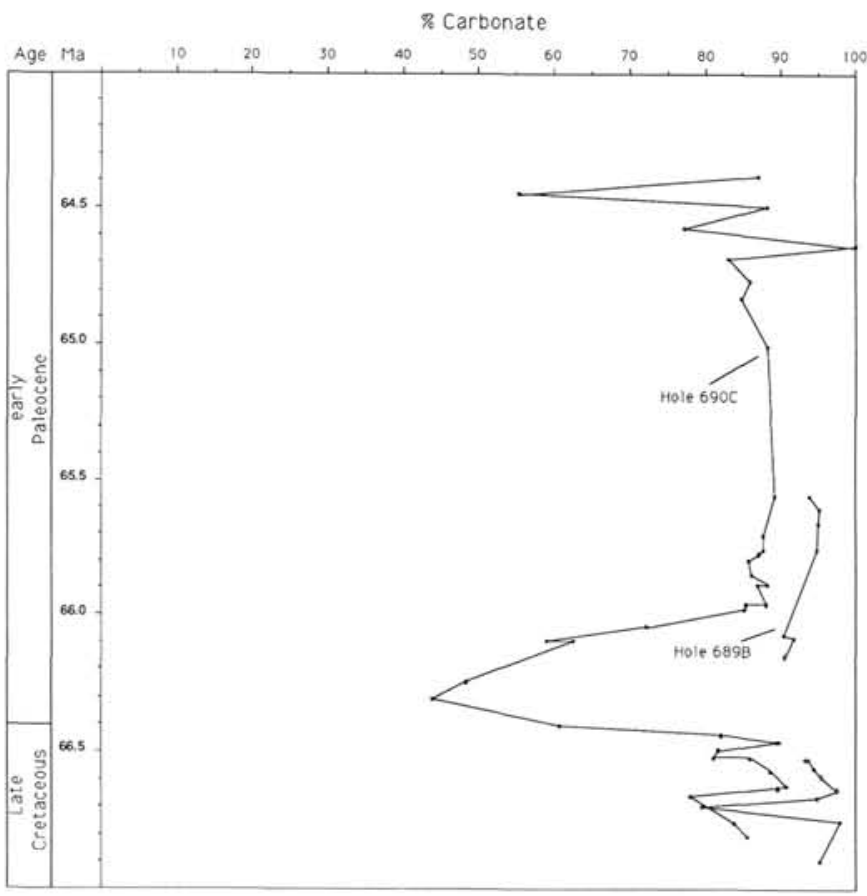

Figure 11. Weight percent calcium carbonate in Holes 689B and $690 \mathrm{C}$ vs. age. There is a marked reduction in \%calcium carbonate across the $\mathrm{K} / \mathrm{P}$ boundary in Hole $690 \mathrm{C}$. Carbonate percentages increase to pre-K/ $\mathrm{P}$ levels by $66 \mathrm{Ma}$ and remain high $(85 \%-90 \%)$ through the early Paleocene. A hiatus in Hole 689B precludes any inference about changes across the boundary in that sequence.

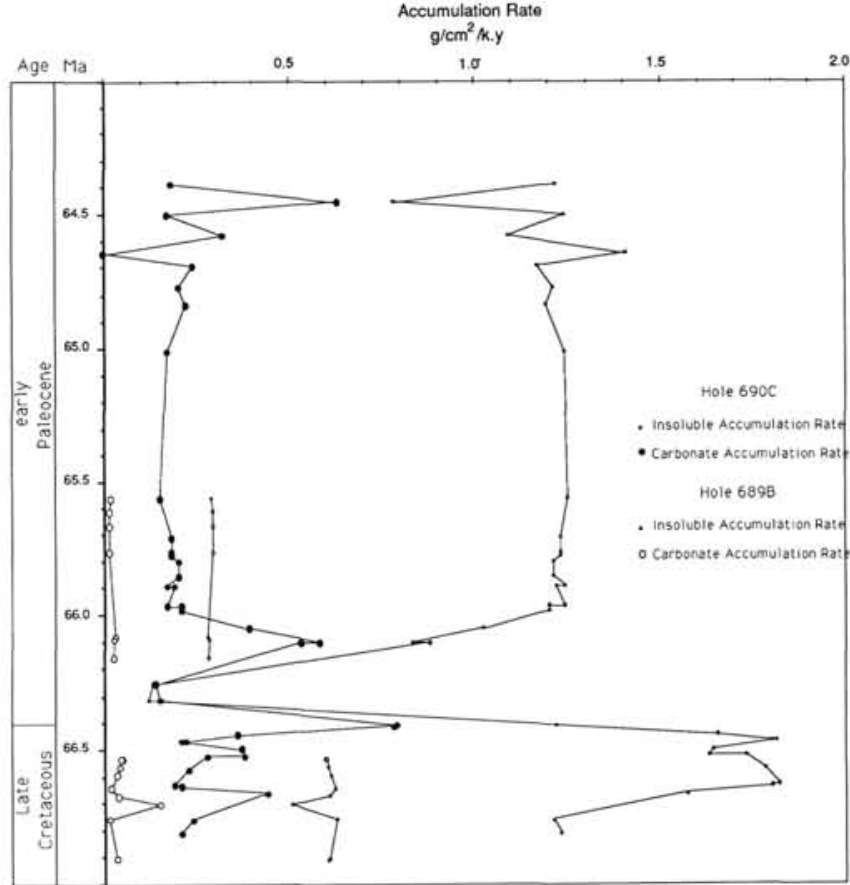

Figure 12. Carbonate and insoluble accumulation rates for Holes 689B and $690 \mathrm{C}$. Carbonate accumulation rates increased relative to insoluble accumulation rates in the latest Cretaceous before declining across the $\mathrm{K} / \mathrm{P}$ boundary. The lowest values occur in the interval between 66.4 and 66.2 Ma. After that, the values increase to a stable level of $\sim 1.25 \mathrm{~g} /$ $\mathrm{cm}^{2} / \mathrm{k}$.y. for the remainder of the early Paleocene.

$\mathrm{g} / \mathrm{cm}^{2} / \mathrm{k}$.y., reaching values of $1.2 \mathrm{~g} / \mathrm{cm}^{2} / \mathrm{k} . \mathrm{y}$. by $\sim 66.0 \mathrm{Ma}$ (Fig. 12). The record from Hole 689B shows a similar record to that of Hole $690 \mathrm{C}$ although a hiatus eliminates the record across the boundary interval. No measurements above $\sim 66.0 \mathrm{Ma}$ were made for this site (Fig. 12). The record from Hole 690C indicates that two events exist in the carbonate accumulation record. The first is a distinct increase in values during the latest Cretaceous which lasted for $\sim 200 \mathrm{k}$.y. between 66.65 and 66.45 $\mathrm{Ma}$. The second distinct event is the sharp decrease in accumulation rates during the earliest Paleocene. Since the carbonate percentages were determined on a relative weight basis, it is possible that the changes in carbonate accumulation rates were caused by changes in the flux of insoluble material to the site. For this reason, insoluble material accumulation rates are also plotted in Figure 12. The changes in insoluble accumulation rate follow that of carbonate accumulation rates. However, it is apparent that the difference between carbonate and total accumulation rates did not remain constant. Specifically, following the sharp increase in carbonate accumulation rates at $66.7 \mathrm{Ma}$, rates began to decrease relative to insoluble accumulation rates during the remainder of the Late Cretaceous (Fig. 12). This pattern is not apparent in the Hole 689B record because of the hiatus which spans the interval. Carbonate and insoluble accumulation rates remained low in the earliest Paleocene with the difference between carbonate and total accumulation rate remaining essentially constant. In the latter part of the $\mathrm{AP} \alpha$ and the early part of the AP1a Zone carbonate accumulation rates began to increase relative to insoluble accumulation rates. It is also notable that in Hole 689B the percent insolubles is much smaller than that of Hole $690 \mathrm{C}$, particularly in the early Paleocene. This suggests that the two Maud Rise sites had different sources for the insoluble-fraction, or that this fraction was winnowed from Site 689 . 


\section{DISCUSSION}

\section{Thermocline Structure, Seasonality, and Global Climate across the $\mathrm{K} / \mathrm{P}$ Boundary}

The oxygen isotopic results presented above indicate that a significant climatic change occurred in the Antarctic Ocean beginning $\sim 500 \mathrm{k}$.y. prior to the mass extinction event at the $\mathrm{K} / \mathrm{P}$ boundary. Planktonic and benthic foraminiferal $\delta^{18} \mathrm{O}$ values decreased by nearly $1.0 \%$ over a relatively short interval, representing an apparent warming of surface and intermediate waters of $\sim 4^{\circ} \mathrm{C}$. The event was short-lived, and was immediately followed by an increase in $\delta^{18} \mathrm{O}$ values during the latest Cretaceous and earliest Paleocene. Benthic values did not increase to earlier Late Cretaceous levels, whereas early Paleocene planktonic values did apparently increase over Late Cretaceous levels. The magnitude and short duration of the initial negative $\delta^{18} \mathrm{O}$ excursion is similar to events recorded at the Paleocene/Eocene boundary (Kennett and Stott, this volume; Stott et al., this volume) and warming preceding the well known isotopic shift at the Eocene/Oligocene boundary. Each of these isotopic changes marked major paleoceanographic events during the Cenozoic. Each occurred over a relatively short period of time and was associated with changes in the marine biota. The Paleocene/Eocene boundary isotopic excursion was associated with the largest benthic foraminiferal extinction of the entire late Phanerozoic (see Thomas, this volume) and was almost certainly coupled to the environmental changes associated with the isotopic excursions (Kennett and Stott, this volume; Stott et al., this volume). The Eocene/Oligocene isotopic shift, although opposite in direction, also marked a major environmental change in the oceans, including a distinct increase in biosiliceous sedimentation in the Antarctic. It is important to note, within this context, that the isotopic excursion that preceded the $\mathrm{K} / \mathrm{P}$ boundary was not associated with distinct changes in the fossil assemblages (see Thomas this volume; Pospichal and Wise, this volume, chapter 32).

Previous investigators of the K/P boundary extinction event have suggested that oceanic (Keller, 1989) and terrestrial (Askin, pers. comm.) climatic changes occurred during the latest Cretaceous, although these have not been well documented. The possibility exists that environmental changes imposed stress on the marine and terrestrial biota, predisposing them to extinction. What potential effects would the temperature changes recorded at Maud Rise have had on the marine biota?

To address the environmental implications of the isotopic excursions observed in the Antarctic record, several factors may have been important: the thickness and seasonal duration of the thermocline prior to, during, and following the isotopic excursions; the extent of temperature change in other parts of the oceans; and additionally, from the perspective of the benthic biota, the nature of deep-water production in the Antarctic during the Late Cretaceous and early Paleocene. At present, we know of no other published latest Cretaceous isotopic record sufficiently detailed to recognize the isotopic excursions commencing near $66.7 \mathrm{Ma}$. Nonetheless, it is possible to make several general observations concerning these factors.

Barrera et al. (1987) suggested that during the Late Cretaceous the shallow continental shelves of the Antarctic were probably a source of cold deep waters, as in the present day. If deep waters did form in the Antarctic, it follows that temperatures as cold as those inferred from benthic isotope values at intermediate water depths at Maud Rise must have formed at the surface at times when temperatures were colder than those recorded by the isotopic values of planktonic foraminifers. It also follows that planktonic foraminifer isotopic temperatures must reflect summer and perhaps spring sea-surface conditions; benthic isotopic temperatures reflect winter sea-surface temperatures. Be- cause the isotopic record indicates a warming of surface and deep waters prior to the $\mathrm{K} / \mathrm{P}$ boundary, year-round temperatures must have warmed in the Maud Rise area. If the planktonic species lived in surface waters during different times of the year and were not governed by a seasonal thermocline, the apparent constancy of isotopic offsets between species during the isotopic excursion might further reflect a uniform, year-round warming, each season warming about equally. If, on the other hand, the isotopic offsets between planktonic species reflect different depth habitats within the seasonal thermocline, the warming event apparently did not cause any change in the vertical thickness of a seasonal thermocline. It might be concluded therefore, that the warming event had little effect on the planktonic or benthic environment beyond a warming of surface and intermediate waters by several degrees.

The well-developed offsets displayed by each planktonic group earlier in the Late Cretaceous were progressively reduced during a short interval of time between 66.6 and $66.4 \mathrm{Ma}$ (Fig. 7). The apparent convergence of isotopic values prior to the $\mathrm{K} / \mathrm{P}$ boundary could indicate a reduction in the thickness of the seasonal thermocline. Such an effect could have been caused by increased upwelling. However, increased upwelling should have produced lower $\delta^{13} \mathrm{C}$ values in the planktonic foraminifers as nutrient-enriched deeper waters reached to the surface, particularly if, as in the modern Antarctic Ocean, nutrients were not taken up completely in the surface waters. There appears to be no reduction in the surface-to-deep water $\delta^{13} \mathrm{C}$ gradients during this time except between benthic values and $H$. globulosa. Planktonic and benthic foraminifers both exhibit increasing $\delta^{13} \mathrm{C}$ values during this interval. There is also no indication that the $\delta^{13} \mathrm{C}$ gradient between planktonic foraminifer taxa themselves changed during this interval (Fig. 10). For these reasons, it is unlikely that increased upwelling would have produced the observed changes in the isotopic values of planktonic foraminifers and calcareous nannofossils prior to the $\mathrm{K} / \mathrm{P}$ boundary biotic crisis. It is more likely that the structure of the thermocline was reduced in response to lower sea-surface temperatures or that there were differential changes in the seasonal temperature contrasts.

\section{Seasonal Thermocline}

In the open ocean today, the thermocline provides the structural framework necessary to maintain the well developed trophic strategies found in these environments (Lipps, 1979). The open ocean, although comprising about $90 \%$ by area, is the poorest region in terms of nutrient availability. These regions are where trophic specialization is greatest and the trophic system is, by necessity, the most highly structured (Valentine, 1973). Even a small change in the structure of the thermocline could produce a change in trophic resources that would lead to a large disruption of the trophic framework (Hallock, 1987). Sediment trap studies in the modern ocean have illustrated the relationship between foraminiferal flux rates, nutrient availability, and the development of a seasonal thermocline. In the subarctic latitudes of the north Pacific, for example, foraminifer production today is highest in the spring when food availability is increasing and the thermal structure of the upper water column is developing (Thunell and Honjo, 1987). Interestingly, planktonic foraminiferal mass flux is lower during the summer even though food is still available. This may result from surface-water temperatures which exceed the temperature tolerances of the foraminiferal assemblage, hence restricting production. Although such changes occur on a seasonal basis, it is clear that carbonate production could be permanently affected if the thermocline was reduced in thickness for an extended period or if the seasonal duration of the thermocline was greatly shortened by the reduction of summer sea-surface temperatures. The extent to which the lower summer flux values are controlled by grazing is not known. 
If the changes observed in the Antarctic isotopic data signify even a small change in the structure of the seasonal thermocline, it may have had a significant effect on the vitality of the Antarctic trophic system as a whole.

\section{Seasonal Sea-Surface Temperatures}

The Late Cretaceous calcareous nannofossils and planktonic foraminifers, such as $G$. multispinatus, exhibiting the lowest $\delta^{18} \mathrm{O}$ values may have lived primarily during the austral summer months. $H$. globulosa, exhibiting slightly higher $\delta^{18} \mathrm{O}$ values, may have inhabited cooler surface waters during spring or fall months. Primary productivity almost certainly would have varied seasonally and could also explain the observed $\delta^{13} \mathrm{C}$ differences between species. The largest $\delta^{18} \mathrm{O}$ increase and therefore, the greatest cooling are recorded in calcareous nannofossils and $G$. multispinatus. On the other hand, $H$. globulosa records a less severe cooling. The isotopic results could, therefore, be interpreted as an indication of cooler summer months. The effect such changes may have had on the Late Cretaceous planktonic foraminifers might be inferred from studies of modern species. Most modern planktonic foraminiferal species are adapted to a narrow temperature range. The subarctic assemblages of the north Pacific mentioned above, for example, appear to have an optimal temperature range of $5^{\circ}-10^{\circ} \mathrm{C}$ (Thunell and Honjo, 1987). Changes in sea-surface temperatures at the North Pacific site cause a systematic seasonal succession of planktonic foraminifer species. Therefore, in addition to the thickness of the thermocline, the range of temperatures appears to have a strong influence on planktonic foraminiferal assemblages. A cooling of several ${ }^{\circ} \mathrm{C}$ during the latest Cretaceous, particularly if it effected spring and summer months, may have disrupted the normal succession of planktonic groups and thus greatly disturbed the trophic network.

Since it is almost certain that the latest Cretaceous foraminfers, like the others since, were adapted to some temperature variability, it is unlikely that the temperature changes themselves were the cause of the mass extinction at the $\mathrm{K} / \mathrm{P}$ boundary. For instance, the sharp warming at $66.7 \mathrm{ma}$ had no apparent detrimental affect on the assemblages. On the other hand, it is possible that the Late Cretaceous plankton became predisposed to extinction by a destabilization of their habitat and trophic structure.

\section{Planktonic and Benthic Carbon Isotope Gradients: Carbon Burial and Paleoproductivity}

The Cenozoic was marked by a number of significant $\delta^{13} \mathrm{C}$ excursions (Shackleton 1986; Miller et al., 1987a); amongst the most notable are those associated with the $\mathrm{K} / \mathrm{P}$ boundary transition. The negative excursion following the $\mathrm{K} / \mathrm{P}$ boundary is well known (Thierstein and Berger, 1978; Boersma and Shackleton, 1979; Arthur et al., 1979; Scholle and Arthur, 1980; Boersma and Shackleton, 1981; Hsü et al., 1982; Williams et al., 1983; Shackleton and Hall, 1984; Zachos and Arthur, 1986; Zachos et al., 1989). Less well documented however, is the positive $\delta^{13} \mathrm{C}$ excursion that immediately preceded the $\mathrm{K} / \mathrm{P}$ boundary (Shackleton et al., 1984; Zachos et al., 1989). In Figure 13 we have plotted the $\delta^{13} \mathrm{C}$ record of benthic foraminifers from Sites 577 (equatorial Pacific; Zachos et al., 1989), Site 527 (South Atlantic; Shackleton et al., 1984), and Holes 689B and 690C from the Antarctic. These sites all contain well-preserved carbonate records across the $\mathrm{K} / \mathrm{P}$ boundary, were at approximately the same paleodepth (2000-2400 m) during the K/P boundary interval and, except for Hole 689B, have good magnetostratigraphic age models. The distinct positive excursion in $\delta^{13} \mathrm{C}$ recorded in the Antarctic sites is also well delineated in benthic isotope records from the other ocean basins.

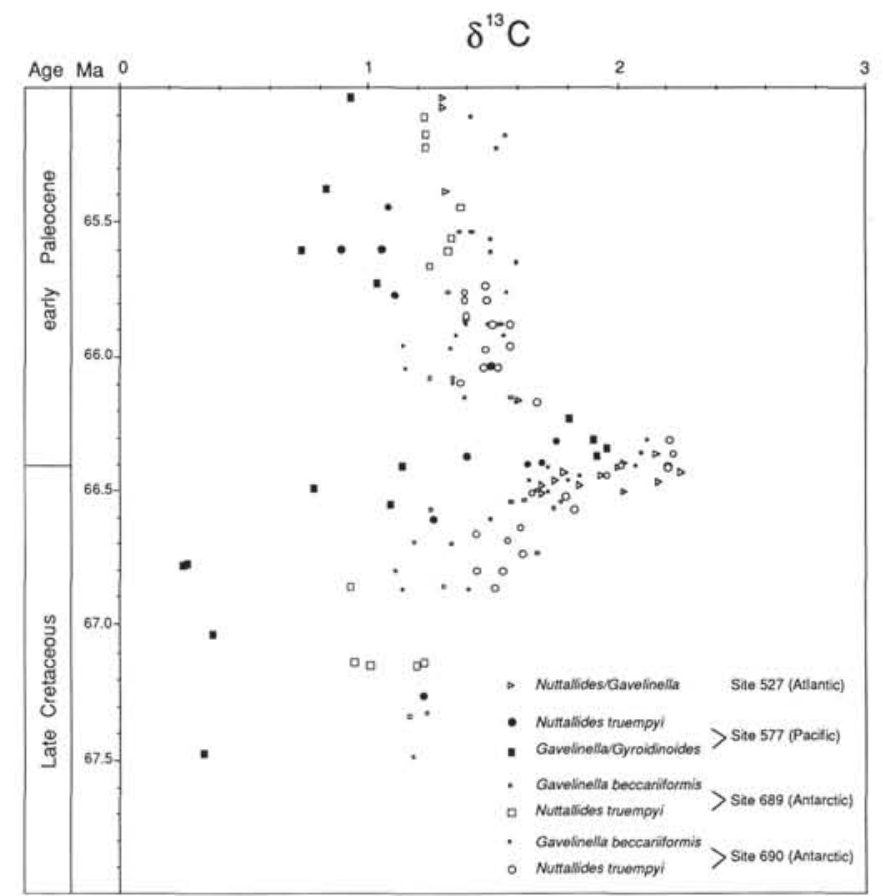

Figure 13. Benthic foraminiferal $\delta^{13} \mathrm{C}$ from Pacific Site 577 (Zachos et al., 1989), South Atlantic Site 527 (Shackleton and Hall, 1984), and Holes $689 \mathrm{~B}$ and $690 \mathrm{C}$ (this study). Isotopic values below the $\mathrm{K} / \mathrm{P}$ boundary reflect a $1 \%$ basin-basin gradient as in the modern ocean (Kroopnick, 1985). Isotopic values in all basins exhibit a marked increase in the interval immediately preceding the $\mathrm{K} / \mathrm{P}$ boundary. At the K/P boundary values converge to $\sim 2.0 \%$, although a gradient still exists between the Atlantic and Pacific. The reduced basin-basin gradient in the socalled Strangelove ocean reflects the reduced biological carbon pump that produces the strong vertical gradients in the oceans today. After about $66.0 \mathrm{Ma}$, when the normal surface-to-deep water $\delta^{13} \mathrm{C}$ gradients were re-established (see Fig. 10) a normal basin-basin gradient is evident.

Zachos et al. (1989) suggested that the positive $\delta^{13} \mathrm{C}$ excursion at Site 577 in the equatorial Pacific prior to the K/P boundary may have been caused by a change in circulation. They also suggested that if the shift was global in scale it may reflect a shift in whole-ocean $\delta^{13} \mathrm{C}$ caused by increased carbon burial in continental margin deposits during a Late Cretaceous eustatic rise. The results from the Pacific, the Atlantic, and the Antarctic (Fig. 13) demonstrate that the positive $\delta^{13} \mathrm{C}$ excursion occurred throughout the oceans. The shift clearly reflects a redistribution of carbon between different reservoirs (i.e., carbonate, organic carbon, atmospheric $\mathrm{CO}_{2}$ ). A major question is whether or not the shift in the oceanic carbon reservoir was linked to the climate change seen in the $\delta^{18} \mathrm{O}$ records through feedback loops in the carbon cycle. If so, which came first, the climate change or the shift in the carbon reservoir? The possibilities include:

1. Increased accumulation of organic carbon in deep sea or continental shelf environments could account for a decrease in atmospheric $\mathrm{pCO}_{2}$. The possibility exists that this caused a reverse greenhouse effect and the global climate cooled. The Antarctic data does not indicate whether the beginning of the positive $\delta^{13} \mathrm{C}$ excursion preceded the positive $\delta^{18} \mathrm{O}$ excursion. The sample spacing does not provide sufficient resolution to resolve this. There was an apparent increase in carbonate accumulation 
rates at Maud Rise, a possible consequence of higher carbonate productivity. However, there is no apparent cause for the sharp warming that began earlier at $66.7 \mathrm{Ma}$.

2. Changes in organic carbon burial relative to carbonate burial was caused by eustatic rise and fall and was independent of any productivity changes. This could explain the $\delta^{13} \mathrm{C}$ excursions in the oceanic TDC reservoir recorded in the benthic foraminifer values. Atmospheric $\mathrm{pCO}_{2}$ fluctuations caused by changes in organic carbon burial could have contributed to global temperature change. However, because there is no physical evidence of ice-sheets during the Late Cretaceous and early Paleocene, a mechanism to produce relatively rapid eustatic changes is lacking.

\section{Mass Extinction, the Strangelove Ocean, and Carbon Cycling}

The coincidence between the mass extinction and the well known negative $\delta^{13} \mathrm{C}$ excursion at the $\mathrm{K} / \mathrm{P}$ boundary supports predictions that primary productivity was diminished at the end of the Mesozoic, the so-called "Strangelove Ocean" (Broecker and Peng, 1982; Hsü and McKenzie, 1985). The data from Hole $690 \mathrm{C}$, however, suggests that, at this locality, productivity was not diminished to the extent suggested by previous studies (Zachos and Arthur, 1986; Zachos et al., 1989). Carbonate accumulation rates do decrease considerably across the $K / P$ boundary and there is a marked reduction in the surface-to-deep water $\delta^{13} \mathrm{C}$ gradient. At no point however, was the $\Delta \delta^{13} \mathrm{C}$ gradient totally eliminated in the Antarctic as in other areas. Other isotopic sequences across the $\mathrm{K} / \mathrm{P}$ boundary indicate that the vertical $\delta^{13} \mathrm{C}$ gradient was totally eliminated and in some cases even reversed (negative $\Delta \delta^{13} \mathrm{C}$; Zachos and Arthur, 1986). The Antarctic data further suggest that the vertical $\delta^{13} \mathrm{C}$ gradient gradually increased in the interval following the extinction. In other areas there is no indication that a vertical gradient began to redevelop until nearly 400 k.y. after the productivity collapse (Zachos and Arthur, 1986).

There are two probable reasons why the Antarctic record provides a somewhat different picture of the Strangelove Ocean. The first results from the fact that the other $\mathrm{K} / \mathrm{P}$ boundary sequences have been analyzed using either bulk carbonate, mixed assemblages of planktonic and benthic foraminifer samples, or discontinuous measurements of single species. As stated earlier, each biogenic component carries a very different isotopic signature depending on its habitat within the water column or the degree to which it secretes its test in isotopic equilibrium. The mixture of more than one of these components in an isotopic sample will bias the result. During the Strangelove interval, the calcareous nannofossil isotopic data from Hole 690C exhibit lower $\delta^{13} \mathrm{C}$ values than even benthic foraminifers. It is difficult to explain these low $\delta^{13} \mathrm{C}$ values when planktonic foraminifers, also surface-water dwellers, show values that are more positive. Possibly all of the species display some degree of positive or negative disequilibrium. Future investigations might include the analysis of several different planktonic species to identify the range of values displayed by planktonic microfossils that lived in the Strangelove Ocean.

Shackleton et al. (1984) previously pointed out that $\delta^{13} \mathrm{C}$ values became increasingly lower following the K/P boundary extinction event, a trend we observe in the Maud Rise data. Shackleton et al. (1984) suggested that this resulted from a build-up of carbon in the oceanic reservoir due to lower carbon accumulation rates, a consequence of the lower productivity and sediment accumulation rates in the early Paleogene. Because of the long residence time of carbon in the ocean $(\sim 200$ k.y.), and the fact that accumulation rates were notably reduced in the post $\mathrm{K} / \mathrm{P}$ interval (Zachos and Arthur, 1986), increased carbon in the oceanic TDC reservoir is a possible explanation for the observed $\delta^{13} \mathrm{C}$ excursion. However, in the modern ocean organic carbon accumulation in deep-sea sediments is only $\sim 4 \%$ of the total particle flux from the euphotic zone (Emerson and Hedges, 1988). Most of the organic carbon accumulation takes place on the margins where productivity and sedimentation rates are higher. Little data exist about changes in sediment or carbon accumulation rates on the continental margins following the $\mathrm{K} / \mathrm{P}$ boundary. If the negative excursion was, as suggested by Shackleton et al. (1984), a consequence of reduced carbon burial in deep-sea sediments because of lower accumulation rates, a positive excursion would be expected after normal productivity $\left(\Delta \delta^{13} \mathrm{C}\right)$ and presumably normal accumulation rates resumed at $66.1 \mathrm{Ma}$. There is no apparent increase in oceanic $\delta^{13} \mathrm{C}$ until late in the Paleocene and this may not have been linked to increased productivity (Miller et al., 1987b). Maximum benthic foraminifer $\delta^{13} \mathrm{C}$ values are similar to those in the pre-K/P boundary interval $(\sim 2.0 \%)$. It is the positive excursion prior to, and at the $\mathrm{K} /$ $\mathrm{P}$ boundary, that is notable. If carbon was tied up in continental margin deposits during a high stand of sea level at the end of the Cretaceous, as suggested by Zachos et al (1989), it is also possible that this carbon reentered the oceanic reservoir during a sea-level regression during the early Paleogene (Haq et al., 1987). The way to address these possibilities includes analyses of barium, $\mathrm{Cd} / \mathrm{Ca}$, and other indicators of nutrient distributions together with the carbon isotopic record and additional information about sediment accumulation rates across the $\mathrm{K} / \mathrm{P}$ boundary (e.g., Stott and Delaney, 1988).

\section{CONCLUSIONS}

The stable isotopic stratigraphies across the $\mathrm{K} / \mathrm{P}$ boundary transition in Maud Rise Holes 689B and 690C provide the first detailed paleoclimatic record for this interval from such high latitudes. The good preservation of the carbonate sediments in Hole $690 \mathrm{C}$ has allowed a detailed, monospecific account of different oceanic habitats within the Antarctic water column. Planktonic foraminifer and calcareous nannofossil isotopic $\delta^{18} \mathrm{O}$ values indicate a significant climatic change beginning $\sim 500$ k.y. before the mass extinction event and before the enrichment of iridium at the $\mathrm{K} / \mathrm{P}$ boundary. This climatic change began with a sharp warming throughout the Antarctic water column. The warming apparently did not effect the structure or thickness of the thermocline if planktonic and benthic values are interpreted in terms of depth habitats. If the isotopic values reflect different seasonal life cycles, the uniform warming of each planktonic and benthic species during this interval could be interpreted as a uniform, year-round, warming in the Antarctic. The warming event did not appear to have been a severe change in the marine biotic environment.

Approximately 200 k.y. prior to the K/P boundary, planktonic and benthic oxygen isotopic values began to increase, a trend that continued to the $\mathrm{K} / \mathrm{P}$ boundary and into the earliest Paleocene. Surface-water cooling also occurred at low latitudes during the latest Cretaceous and this seems to underscore the global extent of this climatic event. In the Antarctic the climatic cooling appears to have been associated with a change in the structure of the thermocline and/or with changes in seasonality as summer temperatures cooled (increased planktonic $\delta^{18} \mathrm{O}$ ) and winter temperatures remained essentially unchanged (smaller benthic $\delta^{18} \mathrm{O}$ change).

A positive shift in both planktonic and benthic $\delta^{13} \mathrm{C}$ occurs in the latest Cretaceous in conjunction with the positive $\delta^{18} \mathrm{O}$ shift. The positive carbon isotope excursion is larger than nearly any other shift recorded during the Cenozoic. Comparisons between isotopic records in the Pacific, the Atlantic, and the Antarctic also indicate that the $\delta^{13} \mathrm{C}$ shift was global in extent and hence, represented a change in the $\delta^{13} \mathrm{C}$ of the ocean TDC reservoir. The association between the carbon reservoir change and the climatic variations recorded in the stable isotopic records 
suggests that the two phenomena might have been related through feedback loops in the carbon cycle.

These events indicate that significant changes took place in the marine environment during the final stages of the Cretaceous. They preceded, by several hundred thousand years, the sudden extinction event at the K/P boundary. Any model to explain the demise of the oceanic plankton at the end of the Cretaceous should consider the oceanic environmental changes that were occurring prior to the massive extinction horizon.

The reduction of planktonic-benthic $\Delta \delta^{13} \mathrm{C}$ across the $\mathrm{K} / \mathrm{P}$ boundary supports previous suggestions that there was a global reduction in primary productivity in the oceans. However, the Antarctic record differs from those of other regions. At Maud Rise the vertical $\Delta \delta^{13} \mathrm{C}$ was not reduced to the extent suggested by other stable isotopic records. The $\Delta \delta^{13} \mathrm{C}$ gradient between planktonic and benthic foraminifers in the Maud Rise sequences began to increase once again shortly after the boundary. This too is different from other records that reflect longer-term reductions of the vertical $\Delta \delta^{13} \mathrm{C}$ gradient. These data may point to geographic differences in the so-called Strangelove Ocean. The true isotopic gradient may be complicated however, by significant disequilibrium effects during the Strangelove interval, particularly in the photoautotrophic or photosymbiont-bearing microfossil groups.

The Maud Rise carbon isotope record across the K/P boundary indicates that a negative excursion similar to that described from other South Atlantic sites occurred approximately 200 k.y. after the $\mathrm{K} / \mathrm{P}$ boundary. This excursion resulted in planktonic and benthic $\delta^{13} \mathrm{C}$ values that were lower than those immediately above the $\mathrm{K} / \mathrm{P}$ boundary. This implies that there was a change in $\delta^{13} \mathrm{C}$ of the oceanic TDC reservoir.

\section{ACKNOWLEDGMENTS}

We express appreciation to the shipboard scientific and technical staff of ODP Leg 113 for collaboration during this research. D. Pak provided essential assistance in this research. Two anonymous reviewers provided useful comments which have helped to improve the manuscript. The research was supported by NSF grants DPP 88-96183 and DPP-89-11554 (Division of Polar Programs) and OCE87-133391, OCE88-173135 (Marine Geology and Geophysics) to J. P. Kennett and USSAC grants FD 20103 to L. D. Stott and FD 20104 to J. P. Kennett.

\section{REFERENCES}

Arthur, M. A., Scholle, P. A., and Hasson, P., 1979. Stable isotopes of oxygen and carbon in carbonates from Sites 398 and 116 of the Deep Sea Drilling Project. In Sibuet, J.-C., Ryan, W.B.F., et al., Init. Repts. DSDP, 47: Washington (U.S. Govt. Printing Office), 477-492.

Barker, P. F., Kennett, J. P., et al., 1988. Proc. ODP, Init. Repts., 113: College Station, TX (Ocean Drilling Program).

Barrera, E., Huber, B. T., Savin, S. M., and Webb, P. -N., 1987. Antarctic marine temperatures: Late Campanian through early Paleocene. Paleoceanography, 2:21-47.

Bé, A.W.H., 1982. Biology of planktonic foraminifera. In Broadhead, T. W. (Ed.), Foraminifera: Knoxville (Univ. Tennessee), 51-91.

Berggren, W. A., Kent, D. V., Flynn, J. J., and Van Couvering, J. A., 1985. Cenozoic geochronology. Geol. Soc. Am. Bull., 96:1407-1418.

Boersma, A., and Shackleton, N. J., 1979. Some oxygen and carbon isotope variations across the Cretaceous/Paleogene boundary in the Atlantic Ocean. In Christensen, K., Birkelund, T. (Eds.), Cretaceous Paleogene Boundary Events Symposium II: Denmark (Univ. Copenhagen), 50-53.

1981. Oxygen and carbon isotope variations and planktonicforaminifer depth habitats, Late Cretaceous to Paleocene, central Pacific, In Thiede, J., Vallier, T. L., et al. (Eds.), Init. Repts. DSDP, 62: Washington (U.S. Govt. Printing Office), 513-526.

Boyle, E., 1981. Cadmium, zinc, copper and barium in foraminifera tests. Earth Planet. Sci. Lett., 53:11-35.
1983. Manganese carbonate overgrowths on foraminifera, Geochim. Cosmochim. Acta, 47:1815-1819.

Boyle, E., and Keigwin, L. D., 1986. Comparison of Atlantic and Pacific paleochemical records for the last 215,000 years: changes in deep ocean circulation and chemical inventories. Earth Planet. Sci Lett., 76:135-150.

Broecker, W. S., and Peng, T. H., 1982. Tracers in the Sea: Palisades, NY (Eldigio Press).

Curry, W. B., and Matthews, R. K., 1981. Paleoceanographic utility of oxygen isotopic measurements on planktic foraminifera: Indian Ocean core-top evidence. Palaeogeogr., Palaeoclimatol., Palaeoecol., 33: 173-191.

Dudley, W. C., Blackwelder, P., Brand, L., and Duplessy, J. -D., 1986. Stable isotopic composition of coccoliths. Mar. Micropaleontol., 10: $1-8$.

Dunbar, R. B., 1983. Stable isotope record of upwelling and climate from Santa Barbara Basin, California. In Thiede B. J., and Suess, E. (Eds.), Coastal Upwelling. Its Sediment Record. Part B: New York (Plenum Press), 217-246.

Emerson, S., and Hedges, J. I., 1988. Processes controlling the organic carbon content of open ocean sediments. Paleoceanography, 3:621634.

Erez, J., and Honjo, S., 1981. Comparison of isotopic composition of planktonic foraminifera in plankton tows, sediment traps and sediments. Palaeogeogr., Palaeoclimatol., Palaeoecol., 33:129-156.

Fairbanks, R. G., Sverdlove, M., Free, R., Wiebe, P. H., and Bé, A.W.H., 1982. Vertical distribution and isotopic fractionation of living planktonic foraminifera from the Panama Basin. Nature, 298: 841-844.

Graham, D. W., Corliss, B. H., Bender, M. L., and Keigwin, L. D., Jr. 1981. Carbon and oxygen isotopic disequilibria of recent deep-sea benthic Foraminifera. Mar. Micropaleontol., 6:483-497.

Hallock, P., 1987. Fluctuations in the trophic resource continuum: A factor in global diversity cycles? Paleoceanography, 2:457-471.

Haq, B. U., Hardenbol, J., and Vail, P. R., 1987. Chronology of fluctuating sea levels since the Triassic ( 250 million years ago to present). Science, 235:1156-1167.

Hsü, K. J., et al., 1982. Mass mortality and its environmental and evolutionary consequences, Science, 216:249-256.

Hsü, K. J., and McKenzie, J. A., 1985. A "Strangelove" Ocean in the earliest Paleogene. In Sundquist, E., and Broecker, W. S. (Eds.), The Carbon Cycle and Atmospheric $\mathrm{CO}_{2}:$ Natural Variations Archean to Present: Washington (Am. Geophys. Union), 487-492.

Kahn, M. I., and Williams, D. F., 1981. Oxygen and carbon isotopic composition of living planktonic foraminifera from the northeas Pacific Ocean. Palaeogeogr., Palaeoclimatol., Palaeoecol., 33:47-69.

Keller, G., 1989. Extended Cretaceous/Tertiary boundary extinctions and delayed population change in planktonic foraminifera from Brazos River, Texas, Paleoceanography, 4:287-332.

Kennett, J. P., 1977. Cenozoic evolution of Antarctic glaciation, the circum-Antarctic ocean and their impact on global paleoceanography J. Geophys. Res., 82:3843-3859.

Killingley, J. S., 1983. Effects of diagenetic recrystallization on ${ }^{18} \mathrm{O} /{ }^{16} \mathrm{O}$ values of deep-sea sediments. Nature, 310:504-507.

Kroopnick, P. M., 1985. The distribution of $\delta^{13} \mathrm{C}$ of SCO2 in the world oceans. Deep-Sea Res., 32:57-84.

Lipps, J. H., 1979. The ecology and paleoecology of planktic foraminifera. In Lipps, J. H., Berger, W. H., Buzas, M. A., Douglas, R. G., and Ross, C. A. (Eds.), Foraminiferal Ecology and Paleoecology. Soc. Econ. Paleontol. Mineral. Short Course, Houston, 6:62104.

Margolis, S. V., Kroopnick, P. M., Goodney, D. E., Dudley, W. C., and Mahoney, M., 1975. Oxygen and carbon isotopes from calcareous nannofossils as paleoclimatic indicators. Science, 189:555-557.

Miller, K. G., Fairbanks, R. G., and Mountain, G. S., 1987a. Tertiary Oxygen Isotope Synthesis, Sea Level History, and continental margin erosion; Paleogene oxygen isotope synthesis, sea level history, and continental margin erosion. Paleoceanography, 2:1-19.

Miller, K. G., Janecek, T. R., Katz, M. E., and Keil, D. J., 1987b. Abyssal circulation and benthic foraminiferal changes near the Paleocene/Eocene boundary. Paleoceanography, 2:741-761

Mix, A. C., 1987. The oxygen-isotope record of glaciation. In Ruddiman, W. F., and Wright, H. E., Jr. (Eds.), North America and adjacent oceans during the last deglaciation, Geol. Soc. Am., 111-113. 
O'Neil, J. R., Clayton, R. N., and Mayeda, T. K., 1969. Oxygen isotope fractionation in divalent metal carbonates. J. Chem. Phys., 51: 5547-5558.

Poore, R. Z., Tauxe, L. Percival, S. F., Jr., Labrecque, J. L., Wright, R., Petersen, N. P., Smith, C. C., Tucker, P., and Hsü, K. J., 1983. Late Cretaceous-Cenozoic magnetostratigraphic biostratigraphic correlations of the South Atlantic Ocean: DSDP Leg 73. Palaeogeogr., Palaeoclimatol., Palaeoecol., 42:127-149.

Scholle, P. A., and Arthur, M. A., 1980. Carbon isotope fluctuations in Cretaceous pelagic limestones: potential stratigraphic and petroleum exploration tool. AAPG Bull., 64:67-87.

Shackleton, N. J., 1974. Attainment of isotopic equilibrium between ocean water and the benthonic Foraminifera genus Uvigerina: Isotopic changes in the ocean during the last glacial. CNRS Res., Colloquium, 219:203-209.

1986. Paleogene stable isotope events. Palaeogeogr., Palaeoclimatol., Palaeoecol., 57:91-102.

Shackleton, N. J., Wiseman, J.D.H., and Buckley, H. A., 1973. Nonequilibrium isotopic fractionation between seawater and planktonic foraminiferal tests. Nature, 242:177-179.

Shackleton, N. J., and Vincent, E., 1978. Oxygen and carbon isotope studies in recent foraminifera from the southwest Indian Ocean. Mar. Micropaleontol. 3:1-13.

Shackleton, N. J., and Hall, M. A., 1984. Carbon isotopic data from Leg 74. In Moore, T. C., Jr., Rabinowitz, P. D., et al., Init. Repts. DSDP, 74: Washington (U.S. Govt. Printing Office), 613-620.

Shackleton, N. J., Hall, M. A., Boersma, A., 1984. Oxygen and carbon isotopic data from Leg 74 foraminifers. In Moore, T. C., Jr., Rabinowitz, P. D., et al., Init. Repts. DSDP, 74: Washington (U.S. Govt. Printing Office), 599-612.

Spero, H. J., and DeNiro, M. J., 1987. The influence of symbiont photosynthesis on the $\delta^{18} \mathrm{O}$ and $\delta^{13} \mathrm{C}$ values of planktonic foraminiferal shell calcite. Symbiosis, 4:213-228.

Spero, H. J., and Williams, D. F., 1988. Extracting environmental information from planktonic foraminiferal $\delta^{13} \mathrm{C}$ data. Nature, 335: 717-719.

Stott, L. D., and Delaney, M., 1988. Cd/Ca in benthic foraminifera and stable isotopes across the Cretaceous/Paleogene boundary at Site 690 (Leg 113), Weddell Sea, Antarctica. EOS, Trans. Am. Geophys. Union, 6:1243.
Thierstein, H., and Berger, W. H., 1978. Injection events in ocean history. Nature, 276:461-466.

Thunell, R. C., and Honjo, S., 1987. Seasonal and interannual changes in planktonic foraminiferal production in the North Pacific. Nature, 328:335-337.

Valentine, J. W., 1973. Evolutionary Ecology of the marine biosphere, Englewood Cliffs, NJ (Prentice-Hall).

Vincent, E., Killingley, J. S., and Berger, W. H., 1981. Stable isotopes in benthic Foraminifera from Ontong-Java Plateau, box cores ERDC 112 and 123. Palaeogeogr., Palaeoclimatol., Palaeoecol., 33:221-230.

Williams, D. F., Sommer, M. A., II, and Bender, M. L., 1977. Carbon isotopic compositions of recent planktonic foraminifera of the Indian Ocean. Earth Planet. Sci. Lett., 36:391-403.

Williams, D. F., Rottger, R., Schmaljohannn, R., and Keigwin, L., 1981. Oxygen and carbon isotopic fractionation and algal symbiosis in the benthic foraminifera, Heterostegina depressa. Palaeogeogr., Palaeoclimatol., Palaeoecol., 33:231-251.

Williams, D. F., Healy-Williams, N., Thunell, R. C., and Leventer, A., 1983. Detailed stable isotope and carbonate records from the upper Maestrichtian-lower Paleocene section of Hole 516F (Leg 72) including the Cretaceous/Tertiary boundary. In Barker, P. F., Carlson, R. L., and Johnson, D. A., et al., Init. Repts. DSDP, 72: Washington (U.S. Govt. Printing Office), 921-930.

Woodruff, F., Savin, S., and Douglas, R., 1981. Biological fractionation of oxygen and carbon isotopes by recent benthic foraminifera. Mar. Micropaleontol. 5:3-11.

Zachos, J. C., and Arthur, M. A., 1986. Paleoceanography of the Cretaceous/Paleogene boundary event: Inferences from stable isotopic and other data. Paleoceanography, 1:5-26.

Zachos, J. C., Arthur, M. A., and Dean, W. E., 1989. Geochemical evidence for suppression of pelagic marine productivity at the Cretaceous/Paleogene boundary. Nature, 337:61-64.

Zimmerman, M. A., Williams, D. F., and Rottger, R., 1983. Symbiontinfluenced isotopic disequilibrium in Heterostegina depressa. $J$. Foram. Res., 13:115-121.

Date of initial receipt: 1 March 1989

Date of acceptance: 24 October 1989

Ms 113B-158 


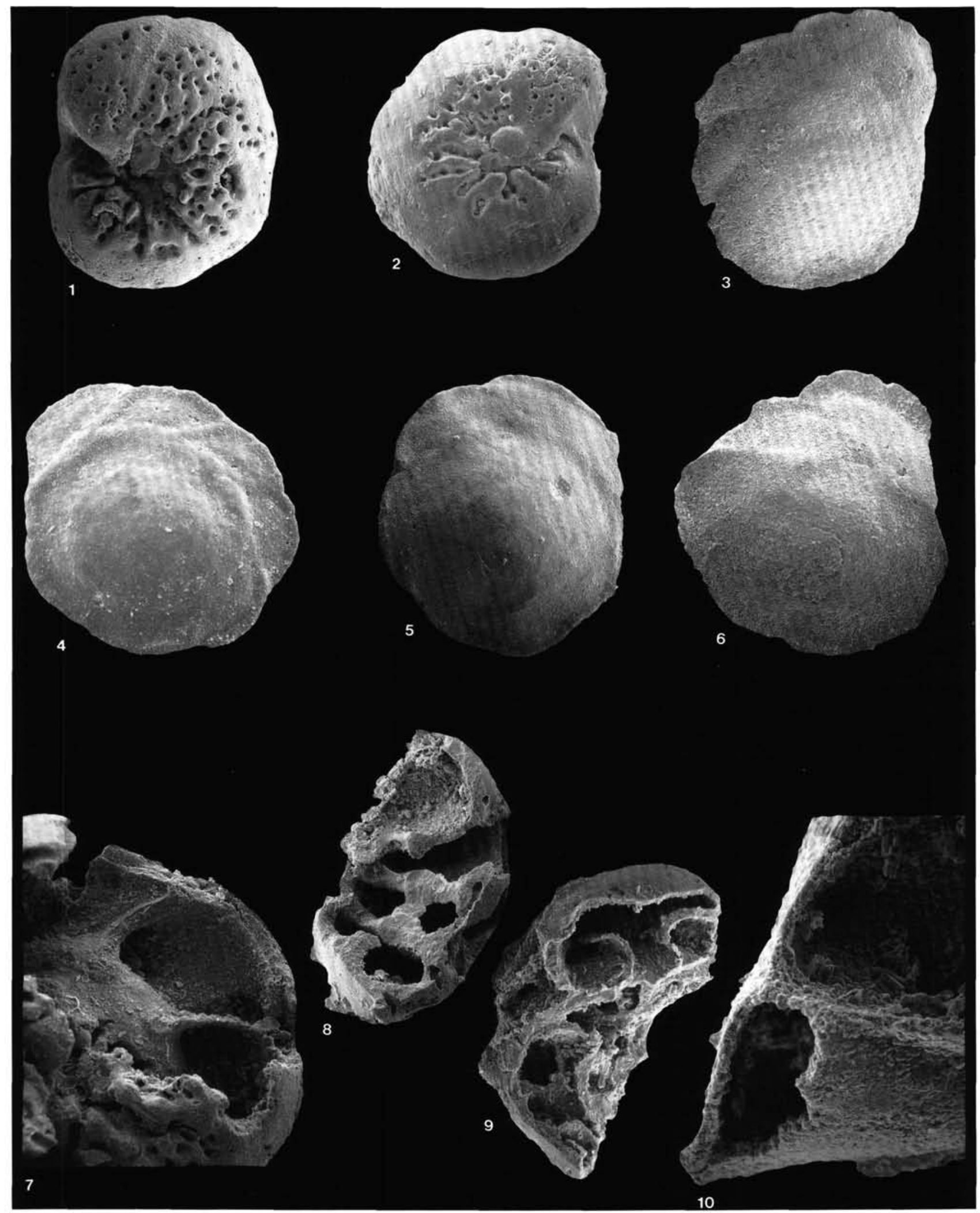

Plate 1. Scanning electron photomicrographs of benthic foraminifers in the K/P boundary interval of the Maud Rise sequences. 1. Gavelinella, Sample 113-689B-25X-5, 51-53 cm, $\times 150$. 2. Gavelinella, Sample 113-690C-15X-4, 28-30 cm, $\times 200$. 3. Osangularia, Sample 113-689B-25X-5, 53-57 cm, $\times 100$. 4. Nuttallides, Sample 113-689B-25X-4, 62-66 cm, $\times 230$. 5. Nuttalides, Sample $113-690 \mathrm{C}-15 \mathrm{X}-3,8-10 \mathrm{~cm}, \times 150$. 6. Osangularia, Sample 113-690C-15X-3, 41-46 cm, $\times 40$. 7. Gavelinella, Sample 113-690C-15X-3, 132-136 cm, $\times 250$; interior of chamber wall showing good preservation. 8. Gavelinella, Sample 113-689B-25X-5, 51-53 cm, $\times 150$; specimen shows minor dissolution of the interior chamber wall but there is no recrystallization evident. 9. Nuttallides, Sample 113-689B-25X-5, 51-53 cm, $\times 300$; showing good preservation of interior of chambers. 10. Osangularia, Sample $113-690 \mathrm{C}-15 \mathrm{X}-4,28-30 \mathrm{~cm}, \times 250$; showing interior of chambers which are covered by small crystal overgrowths. The wall structure does not appear to be recrystallized. Specimens exhibiting this feature are rare in the sequences. 

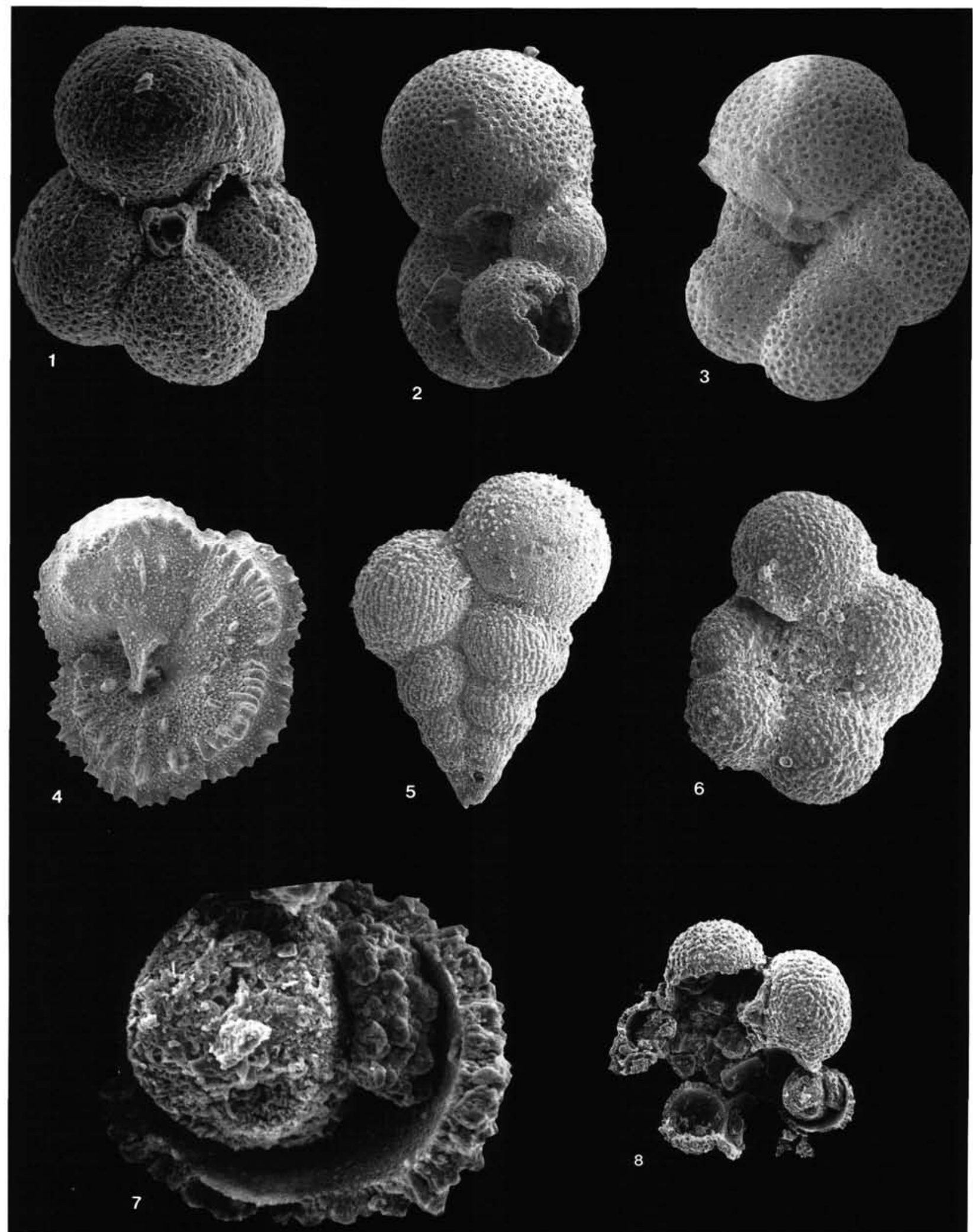

Plate 2. Scanning electron photomicrographs of planktonic foraminifers common in the K/P boundary interval of Maud Rise sequences. 1. Eoglobigerina fringa, Sample 113-690C-15X-4, 28-30 cm, $\times 200$. 2. Eoglobigerina trivialis, Sample 113-690C-15X-4, 28-30 cm, $\times 250$. 3. Subbotina pseudobulloides, Sample $113-690 \mathrm{C}-14 \mathrm{X}-3,36-40 \mathrm{~cm}, \times 300$. 4. Abathomphalus mayaroensis, Sample $113-689 \mathrm{~B}-22 \mathrm{X}-5,79-81 \mathrm{~cm}, \times 200$. 5. Heterohelix globulosa, Sample 113-689B-22X-5, 79-81 cm, $\times 200$. 6. Globigerinelloides multispinatus, Sample 113-690C-15X-4, 45-47 cm, $\times 200$. 7. G. multispinatus, Sample $113-690 \mathrm{C}-15 \mathrm{X}-4,45-47 \mathrm{~cm}$, showing the well preserved calcite of the chamber walls and also the clay infilling, $\times 775$. 8. same specimen as $7, \times 155$. The clay infilling is readily identified under normal light microscopy. These specimens are not included in the isotopic samples. 